\title{
Influence of glacier runoff on ecosystem structure in Gulf of Alaska fjords
}

\author{
Mayumi L. Arimitsu ${ }^{1, *}$, John F. Piatt ${ }^{2}$, Franz Mueter ${ }^{3}$ \\ ${ }^{1}$ US Geological Survey, Alaska Science Center, 250 Egan Dr., Juneau, AK 99801, USA \\ ${ }^{2}$ US Geological Survey, Alaska Science Center, 4210 University Dr., Anchorage, AK 99508, USA \\ ${ }^{3}$ University of Alaska Fairbanks, School of Fisheries and Ocean Sciences, 17101 Point Lena Loop Rd., Juneau, AK 99801, USA
}

\begin{abstract}
To better understand the influence of glacier runoff on fjord ecosystems, we sampled oceanographic conditions, nutrients, zooplankton, forage fish and seabirds within 4 fjords in coastal areas of the Gulf Alaska. We used generalized additive models and geostatistics to identify the range of glacier runoff influence into coastal waters within fjords of varying estuarine influence and topographic complexity. We also modeled the response of depth-integrated chlorophyll a concentration, copepod biomass, fish and seabird abundance to physical, nutrient and biotic predictor variables. The effects of glacial runoff were traced at least $10 \mathrm{~km}$ into coastal fjords by cold, turbid, stratified and generally nutrient-rich near-surface conditions. Glacially modified physical gradients, nutrient availability and among-fjord differences explained $67 \%$ of the variation in phytoplankton abundance, which is a driver of ecosystem structure at higher trophic levels. Copepod, euphausiid, fish and seabird distribution and abundance were related to environmental gradients that could be traced to glacial freshwater input, particularly turbidity and temperature. Seabird density was predicted by prey availability and silicate concentrations, which may be a proxy for upwelling areas where this nutrient is in excess. Similarities in ecosystem structure among fjords were attributable to an influx of cold, fresh and sediment-laden water, whereas differences were likely related to fjord topography and local differences in estuarine vs. ocean influence. We anticipate that continued changes in the timing and volume of glacial runoff will ultimately alter coastal ecosystems in the future.
\end{abstract}

KEY WORDS: Glacier · Freshwater · Turbidity · Inorganic nutrients $\cdot$ Chlorophyll a Copepod · Euphausiid · Forage fish · Seabird · Generalized least squares · Boosted regression trees

\section{INTRODUCTION}

Glacial runoff provides a seasonal pulse of cold, sediment-laden freshwater to highly productive coastal areas of the Gulf of Alaska. Southern coastal Alaska has the largest system of temperate ice fields and glaciers in North America, nearly all of which are thinning and receding (Larsen et al. 2015). Rapid melting of coastal glaciers along the Gulf of Alaska is contributing to rising global sea level (Jacob et al. 2012) and has the potential to alter the physical, chemical and ecological properties of downstream freshwater and marine ecosystems (Syvitski et al.

${ }^{*}$ Corresponding author: marimitsu@usgs.gov
1987, O'Neel et al. 2015). For example, freshwater runoff from glaciers (i.e. liquid water and ice discharged at the glacier terminus) affects large-scale circulation and productivity in the region (Weingartner et al. 2005). Tidewater glaciers terminate at the sea in many of Alaska's major fjords, which provide wintering, breeding, nursery and feeding habitat for marine predators of economic importance and conservation concern (Womble et al. 2010, Piatt et al. 2011, Nielsen et al. 2014). Understanding the ecosystem dynamics of this glacially influenced region will help predict how continued climate warming will affect these important resources.

() The authors 2016. Open Access under Creative Commons by Attribution Licence. Use, distribution and reproduction are unrestricted. Authors and original publication must be credited. 
Nearly half (47\%) of the annual freshwater discharge into the Gulf of Alaska originates from glaciers (Neal et al. 2010), although discharge estimates may vary over space and time throughout the region (Hill et al. 2015). This freshwater input, along with abundant rainfall and snowmelt, maintains the density gradient that drives the Alaska Coastal Current and significantly influences marine productivity in nearshore regions of the Gulf of Alaska (Royer et al. 2001).

The delivery of glacial runoff to coastal systems and the resulting influence on marine habitat depends on the glacier terminus position relative to submarine geomorphology (Syvitski et al. 1987, Syvitski 1989, Motyka et al. 2003). Freshwater discharge may enter the ocean at depth below tidewater glaciers, which can cause localized upwelling and mixing near the glacier front and also influence estuarine circulation (Straneo et al. 2011, Bartholomaus et al. 2013). In contrast, discharge from glaciers that have grounded near or above the shoreline behaves like riverine discharge, which influences surface stratification and estuarine circulation (Stigebrandt 1981). Floating ice calved from glaciers also brings cool fresh melt water into coastal marine waters. This is an important process where glacier mass loss from calving exceeds melting rates (Post et al. 2011).

Glacial fjord ecosystems offer an opportunity to examine trophic relationships relative to marine habitat within rapidly changing marine ecosystems. Glacier runoff provides a link between terrestrial systems and nearshore coastal processes (Fellman et al. 2010), whereby freshwater input influences the physical oceanographic properties and circulation of fjords (Etherington et al. 2007, Hill et al. 2009). Environmental gradients caused by glacial runoff into the marine environment shape marine communities in fjords in Alaska (Renner et al. 2012) and Svalbard (Lydersen et al. 2014, Dalpadado et al. 2016). Phytoplankton are limited by light availability due to high sediment loads near glaciers (Burrell 1988, Piwosz et al. 2009), and we hypothesize that the abundance of phytoplankton in glacier fjords may also be related to changes in temperature, stratification and nutrient availability (Gargett 1997). Despite low phytoplankton abundance, these pro-glacial systems are occupied by a variety of marine consumers, including an abundance of copepods, euphausiids and cold-water spawning forage fish (Arimitsu et al. 2008, Renner et al. 2012), seabird colonies and feeding aggregations (Mehlum \& Gabrielsen 1993) and marine mammals that haul out on floating ice (Blundell et al. 2011).
The overarching goal of this work was to compare and contrast the influence of glacier runoff on fjord ecosystems across the Gulf of Alaska. We sought to (1) describe the magnitude and horizontal range of influence of key near-surface physical characteristics associated with glacial runoff in coastal marine waters, and (2) characterize the distribution and response of lower- to upper-trophic level organisms relative to glacially influenced habitat gradients. We sampled oceanographic variables, nutrients, plankton, fish and seabirds at each of 172 stations within 3 study regions encompassing 4 fjord systems in the Gulf of Alaska. We used generalized additive models and geostatistics to characterize horizontal gradients in environmental conditions relative to glacier runoff sources, and parametric methods to model the response of chlorophyll a ( $\mathrm{chl}$ a), zooplankton, fish and seabirds relative to physical, chemical and biological indices in glacial fjords.

\section{MATERIALS AND METHODS}

\section{Study area}

In order to understand marine ecosystem responses to a range of habitat variability in coastal zones modified by glacial freshwater outflows, biophysical data were collected in 3 study regions that included 4 major glacial fjord systems around the Gulf of Alaska (Fig. 1). The fjord systems were chosen to represent a range of oceanographic conditions and fjord complexity within heavily glaciated regions of the southern Alaska coast. College Fjord and Harriman Bay, sampled on July 22-27, 2010, are located in northern Prince William Sound (PWS), a large semi-enclosed estuarine embayment in south-central Alaska. College and Harriman Fjords both experience strong glacier influence branching from a deep channel that is protected from direct oceanic influence. Icy Bay and Yakutat Bay (IBYAK), sampled July 8-20, 2011, are located in southeast Alaska and experience direct oceanic influence from the Gulf of Alaska. In IBYAK, glacial runoff sources include the tidewater glaciers near the heads of the bays as well as glacial rivers entering nearshore areas adjacent to the Malaspina Icefield, a large piedmont glacier that separates the 2 bays. Glacier Bay (GLBA), sampled June 22-30 and July $6-14,2004$, is an estuarine fjord system with strong tidal influences and multiple topographic constrictions. In GLBA, two narrow fjords (Muir Inlet and the West Arm) terminate in tidewater glaciers in the 
north and more oceanic influence is observed at its southern entrance. Each of 172 discrete stations within the 3 study regions was sampled once during the peak ice-melt season in summer. This single 'snapshot' approach made it impossible to assess within-season or interannual variability, which may contribute to the regional differences we observed among fjords in our study. However, independent studies on the effects of strong environmental gradients on marine communities in estuarine systems of coastal Alaska suggest spatial variability may play a more important role than interannual variability over relatively short time scales (Robards et al. 1999, Abookire \& Piatt 2005, Speckman et al. 2005, Etherington et al. 2007, Arimitsu et al. 2012).

\section{Data collection and processing}

To sample environmental conditions and associated abundances of plankton, fish and seabirds relative to the range in marine habitat conditions observed, sampling stations in each fjord were chosen randomly from a $2.5 \times 2.5 \mathrm{~km}$ grid overlaid on navigable waters in the fjord. The number of stations in each fjord was chosen to achieve a sampling frequency of about 1 sample per $15 \mathrm{~km}^{2}$, and was based on available resources and logistical constraints (weather, navigational hazards and vessel time). A suite of geographic, oceanographic, nutrient and biological attributes was sampled at each station (Table 1, for details see Renner et al. 2012). Briefly, seabird densities were esti-

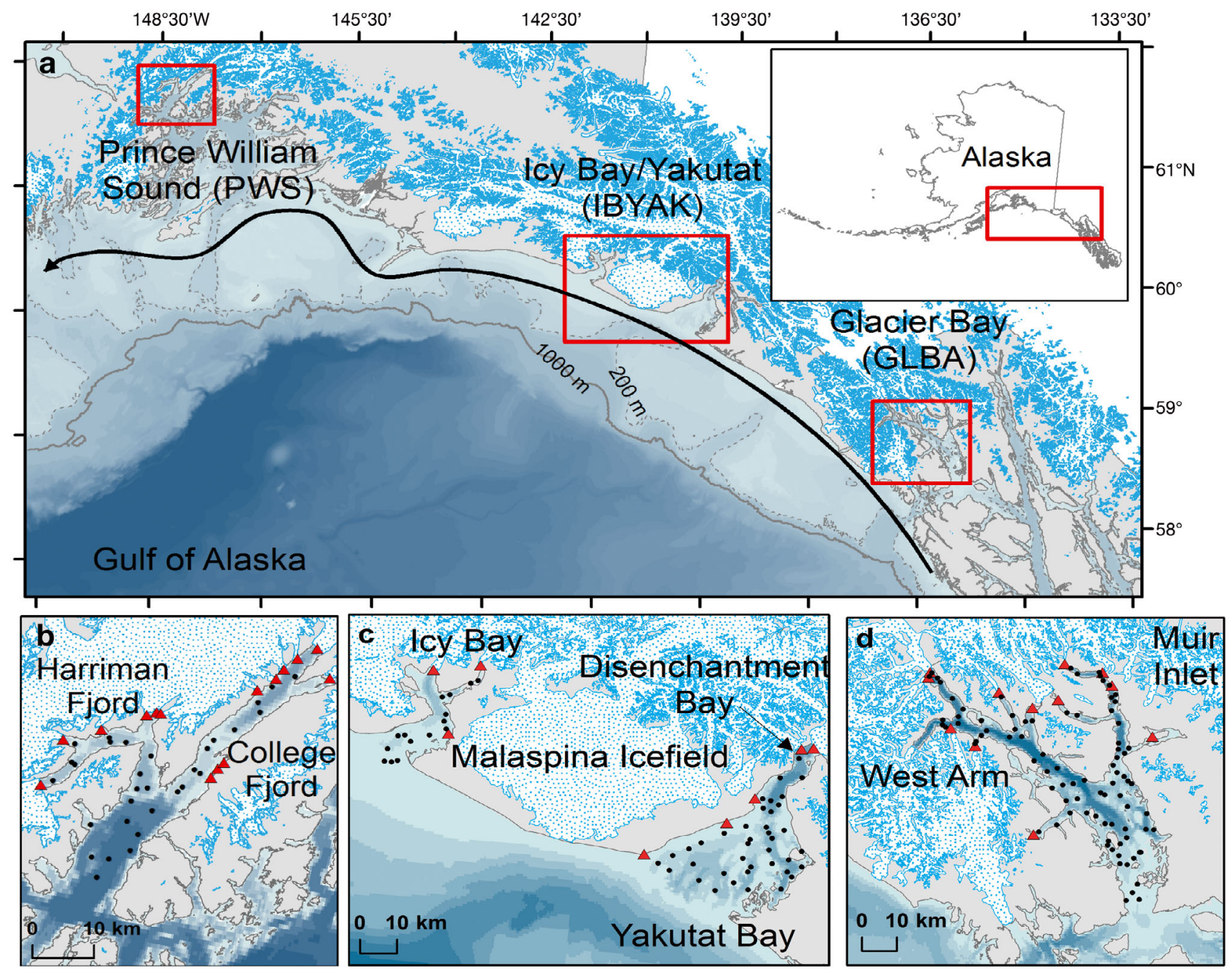

Fig. 1. (a) Study locations with site abbreviations and general coastal path of the Alaska Coastal Current (black arrow). Bathymetric contours are shown at $200 \mathrm{~m}$ (dashed) and $1000 \mathrm{~m}$ (solid), and relief shading indicates seafloor depth with darker shades indicating deeper depth. (b,c,d) Sample sites (black circles) and glacier runoff sources (red triangles) in 4 fjord systems: (b) Prince william Sound (PWS), (c) Icy Bay and Yakutat Bay (IBYAK), and (D) Glacier Bay (GLBA). Bathymetry and glacier coverage (blue stipple) courtesy of Lindquist et al. (2004) and Arendt et al. (2014), respectively 


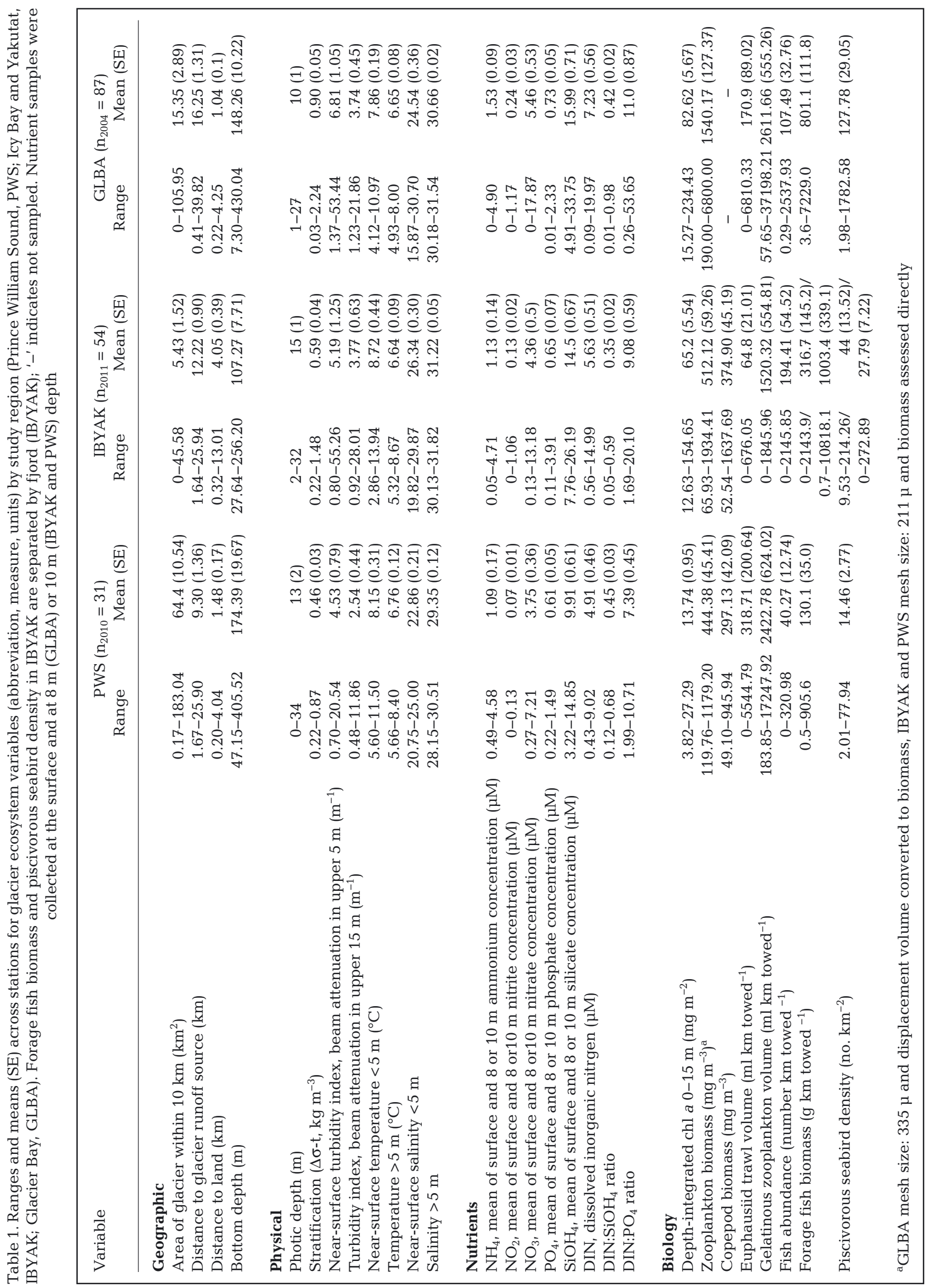


mated at each station with a $300 \mathrm{~m}$ strip transect using standardized at-sea survey methods (Gould \& Forsell 1989). Although we made efforts to avoid double-counting animals during surveys, estimated bird densities are not comparable with other seabird censuses (e.g. Piatt et al. 2011) owing to the slow vessel speed while trawling (2-3 knots). During each 45 min marine bird transect, fish were sampled by towing a modified herring midwater trawl with diminishing mesh size from 5 to $1 \mathrm{~cm}$ with an approximately $50 \mathrm{~m}^{2}$ mouth opening in near surface waters. The same net was used in all study regions to target near-surface waters (mean tow depth $\pm \mathrm{SE}=12 \pm 1 \mathrm{~m}$ ). Different research platforms (22 m F/V 'Steller' in GLBA, $15 \mathrm{~m}$ R/V 'Alaskan Gyre' at IBYAK and PWS), captains and deck gear were employed and this resulted in shallower mean depth of the head rope in GLBA (5 m) compared to IBYAK and PWS (20 and $21 \mathrm{~m}$, respectively). Selectivity of this net is unknown but previous work indicated the net is effective at catching small (usually $<20 \mathrm{~cm}$ ) schooling fish and euphausiids in a variety of coastal habitats (Speckman et al. 2005, Renner et al. 2012). Distance towed was estimated with a flowmeter (mean transect length $\pm \mathrm{SE}=2.78 \pm$ $0.06 \mathrm{~km})$. Zooplankton and oceanographic measures were collected at the beginning or end of each transect. Zooplankton were sampled with a multinet (0.5 $\mathrm{m}^{2}$ mouth opening with $335 \mu$ mesh in GLBA) or a ring net $(0.6 \mathrm{~m}$ diameter with $211 \mu$ mesh in IBYAK and PWS stations) on a $50 \mathrm{~m}$ vertical haul or to within $5 \mathrm{~m}$ of the bottom in shallow water. Because we used different nets for sampling zooplankton in GLBA vs. other sites, comparisons could only be made between IBYAK and PWS zooplankton datasets. Chl a and inorganic nutrients were sampled with a water sampler near the surface and at $10 \mathrm{~m}$ depth (or at surface and $8 \mathrm{~m}$ in GLBA), and oceanographic conditions were sampled with a Seabird Electronics SBE25 (GLBA) or SBE19 (PWS and IBYAK) CDT profiler equipped with sensors to measure in situ temperature, salinity, chl a (WetStar WET Labs), photosynthetically active radiation (PAR, LI-193 Spherical Quantum Sensor), and beam attenuation (C-Star WET Labs). Hydrographic sensors were calibrated by the manufacturers within 14 mo of sampling.

Trawl catches were weighed and total volume was measured in the field. Large catches were subsampled by volume. Fish were identified and enumerated by species and the fork lengths of up to 50 individuals from each species were measured in the field, and a subset of common fish (see Table 3) were weighed in the lab to estimate forage fish biomass. Euphausiids and gelatinous zooplankton total vol- ume and wet weight were measured, but individuals were not identified to species. Zooplankton and trawl-caught larval fish that could not be identified in the field were preserved in $3-5 \%$ or $10 \%$ formalin, respectively. Water samples for inorganic nutrient concentration $(\mu \mathrm{M})$ analysis were frozen in clean $60 \mathrm{ml}$ HDPE sample bottles and later processed at the University of Washington Marine Chemistry lab using established protocols (UNESCO 1994). Chl a samples were processed by filtering $68 \mathrm{ml}$ of sample water through GFF filters that were kept in dark conditions and frozen immediately. Acetone extraction and laboratory fluorometry of discreet depth chl a samples for calibration of in situ fluorometer values are described in detail in Arimitsu et al. (2008).

Laboratory processing methods for zooplankton samples differed for each gear type. IBYAK and PWS ring net samples were identified to species and life stage whenever possible, up to 10 individuals per species/life stage were weighed, and abundance was estimated using a plankton splitter after large organisms were counted and removed. After summing the weights by species and dividing by volume filtered, total zooplankton and copepod biomass $\left(\mathrm{mg} \mathrm{m}^{-3}\right.$, IBYAK and PWS only) was calculated for each station in these study regions. These samples were processed at the University of Alaska Fairbanks. For GLBA multinet samples, bulk zooplankton samples were processed by estimating displacement volume to the nearest $0.25 \mathrm{ml}$, converting displacement volume to relative wet mass assuming $800 \mathrm{mg} \mathrm{cm}^{-3}$ (Harris et al. 2000, p. 140) and dividing by the volume filtered $\left(\mathrm{m}^{3}\right)$. The difference in sampling and processing methods preclude direct comparison of zooplankton biomass between GLBA and other study regions.

Dataset variables were summarized using selected study region-specific indices for descriptive and modeling purposes (Table 1). Geographic variables - including distance to land, distance to the nearest tidewater glacier, recently grounded glacier or major glacier river outflow (Fig. 1) and the total area of glaciers within $10 \mathrm{~km}$ of a station-were estimated using GIS. Distances were measured from each station's transect midpoint. The current extent of glaciers was estimated by data provided by the Randolph Glacier Inventory (Arendt et al. 2014). Oceanographic variables were summarized by averaging the upper $5 \mathrm{~m}$ (near-surface temperature, salinity and near-surface beam attenuation, which is a measure of the loss of light as a result of absorption and scattering from suspended particles, hereafter called 'turbidity'), $15 \mathrm{~m}$ (turbidity) and $50 \mathrm{~m}$ (temperature, salinity) of the water column. These depths were cho- 
sen to summarize the data because conditions from 0-5 $\mathrm{m}$ depths are most representative of the glacial freshwater signal (Etherington et al. 2007), while 15 or $50 \mathrm{~m}$ depth-averaged conditions were most representative of the conditions experienced by the organisms we sampled. Photic depth was estimated as the depth at which the PAR value reached $1 \%$ of the surface value. A stratification index was calculated as the average change per meter in density $(\Delta \sigma$-t) within the upper $10 \mathrm{~m}$ of the water column (Etherington et al. 2007). Near-surface nutrient concentrations were calculated as the average of concentrations at the surface and at $8 \mathrm{~m}$ (GLBA) or $10 \mathrm{~m}$ (IBYAK and PWS) depths. Because of strong correlations among the nutrient variables, we used principal components analysis (PCA) to capture the variability in dissolved inorganic nitrogen (DIN, sum of nitrate $\mathrm{NO}_{3}$, nitrite $\mathrm{NO}_{2}$ and ammonium $\left.\mathrm{NH}_{4}\right)$, silicate $\left(\mathrm{SiOH}_{4}\right)$ and phosphate $\left(\mathrm{PO}_{4}\right)$ concentrations. The near-surface nutrient index for each station was equal to the first principal component score (PC1_nutrient), which explained $82 \%$ of the variability in nutrients, and was positively associated with $\mathrm{DIN}, \mathrm{PO}_{4}$ and $\mathrm{SiOH}_{4}$ (loadings: $0.61,0.55$ and 0.58 , respectively).

Response variables for modeling biological vari-

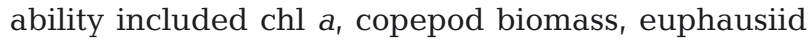
volume, fish abundances and seabird density. Indices were transformed to approximate normality and centered by subtracting the overall means for modeling purposes. Calibrated fluorometer chl a concentrations were integrated over the upper $15 \mathrm{~m}$ of the water column and fourth-root transformed. Copepod biomass data by species (Table 1) were summed to represent total copepod biomass at each station and $\log$ transformed. Gelatinous zooplankton volume, euphausiid volume and age 1+ fish abundance (excluding young-of-the-year fish) was standardized by the length of the trawl tow in $\mathrm{km}$. Seabird density was calculated by summing the number of pelagicfeeding marine birds (see Table 3) sighted on the water within $150 \mathrm{~m}$ on either side of the vessel and dividing by the area of the transect. Brachyramphus murrelets identified to genus level in the field were assigned to species using methods described in Arimitsu et al. (2011). Fish and seabird response variables were $\log (x+1)$ transformed prior to modeling. To model seabird density, we estimated prey availability using forage fish biomass in trawls, which was calculated by subtracting the biomass of adult pollock from the total fish catch weight. Adult pollock, the largest species in trawl catches, were excluded because they are generally too large to be consumed by foraging seabirds.

\section{Data analysis}

Range of melt water influence

Freshwater runoff creates variability in nearsurface fjord conditions (Gibbs et al. 2000, Silva et al. 2011), so we examined temperature $(0-5 \mathrm{~m})$, turbidity $(0-5 \mathrm{~m})$, stratification $(\Delta \sigma-\mathrm{t}<10 \mathrm{~m})$, salinity $(0-$ $5 \mathrm{~m})$ and nutrients $(<10 \mathrm{~m})$ to better understand the range of glacier melt-water influence. We used generalized additive models (GAMs) to evaluate the response of near-surface temperature, stratification, turbidity and PC1_nutrients in relation to the distance to nearest glacier runoff source in each study region (Fig. 1, Table 1).

We used detrended ordinary kriging to map nearsurface conditions in each study region assuming second order stationarity and underlying spatial autocorrelation. Range, sill and nugget parameters for the spatial autocorrelation were estimated using weighted least squares regression implemented in the 'geoR' package (Diggle \& Ribeiro 2007) using $\mathrm{R}$ statistical software (v.3.1.2, R Development Core Team 2014). Euclidean distance was inappropriate for estimating pairwise distances due to the convoluted shorelines in GLBA and IBYAK, therefore we calculated pairwise distance through the water between points using the 'gdistance' package (van Etten 2015), and used PCA to create transformed coordinates that preserved these distances as much as possible. A first-order geospatial trend model with either Gaussian or exponential autocorrelation, depending on the variogram fit, was estimated via ordinary kriging. Predicted values were obtained at $1 \mathrm{~km}$ resolution within the maximum extent of the sample data, and back transformed for mapping in GIS.

\section{Chl a}

Our a priori hypothesis was that phytoplankton abundance is related to nutrients, light and stratification (Gargett 1997). Because of strong multicollinearity among the explanatory variables related to glacier melt water, including DIN, $\mathrm{SiOH}_{4}, \mathrm{PO}_{4}$, turbidity, temperature, and stratification, we conducted a PCA to obtain a reduced set of uncorrelated principal components (PC_glacier) for modeling purposes. We explored ordinary least squares (OLS) models that included PCs and study region, and their interactions. Best-fit models were determined on the basis of minimum Akaike information criteria (AIC), and 
Moran's I test for autocorrelation was used to assess whether residuals were independent. Where spatial autocorrelation was identified (Moran's I test $\alpha<$ 0.05), generalized least squares (GLS) models were fit with an exponential correlation structure using transformed coordinates to preserve distance through the water (as above). GLS models were first fit using maximum likelihood estimation to allow comparison of AIC values among models. A likelihood ratio test (LRT) was then used to assess the overall significance of the model with the lowest AIC relative to the null model. Finally, the AIC-best model was re-fit with restricted maximum likelihood (REML) for improved parameter estimates (Pinheiro $\&$ Bates 2000). The proportion of variance explained by the final GLS model was calculated as 1 - (variance of the residuals) /(variance of the response).

\section{Zooplankton, euphausiids, fish and seabirds}

Our main objective was to fit a parsimonious model to describe the relationship between 4 response variables representing biomass, presence/absence or abundance of different trophic levels and the most influential predictor variables. Response variables for modeling included copepod biomass (PWS and IBYAK only), euphausiid presence/absence (0/1), fish abundance and seabird density. Because of the large number of explanatory variables (Table 1), we used an exploratory approach to identify potentially important predictor variables and possible interactions for inclusion in modeling efforts. To identify predictors with the highest predictive accuracy we used boosted regression trees (BRT), a tree-based machine learning technique that applies a stochastic gradient boosting algorithm to improve predictive performance (Friedman 2001, Elith et al. 2008). BRT uses stochastic numerical optimization to minimize predictive deviance by fitting a large number of classification and regression trees to the data (De'ath 2007). The algorithm begins with a single tree, then weights each successive tree based on the incorrectly classified observations in the previous tree. The final classification is determined by optimized weighted majority of classifications and $k$-fold cross-validation (see details in Elith et al. 2008). We specified a Gaussian distribution for copepod, fish and seabird responses in the BRT models. Due to the large number of zeros (66\% of stations across study regions) in the euphausiid catch, however, we used presence/ absence data in the BRT analysis, which was modeled as a binomial response variable. We tested mul- tiple parameter settings and found the models with lowest predictive deviance resulted when we set the learning rate to 0.001 , bag fraction to $0.5,5$-fold cross validation, and adjusted the tree complexity (from 1 to 5) for optimal prediction. The strength of firstorder interactions between predictors was quantified using functions provided in Elith et al. (2008) and the 'gbm' package (Ridgeway 2013). In addition to variables that represented prey indices (e.g. chl a for copepods), and the categorical variable to account for study region $(n=3)$ or fjord differences $(n=4)$, predictors identified with high relative influence (generally $>10 \%$ ) in the BRT analysis were subsequently used in OLS or GLS (when Moran's I test indicated autocorrelation in OLS residuals at $\alpha<0.05$ ) regression models using the same methods for model choice and diagnostics employed for the chl a model. Euphausiid presence/absence data was modeled using a binomial GLM with a logit link to estimate the probability that euphausiids are present. The performance of the AIC-best GLM model was evaluated on the basis of the proportion of fitted probabilities that resulted in correct classification of the response, where euphausiids were predicted to be present if the estimated probability exceeded 0.50 .

\section{RESULTS}

\section{Range of melt water influence}

The presence or effect of glacier runoff could be tracked at least $10 \mathrm{~km}$ distant (hereafter called 'downstream') from glacier runoff sources by its signature of cooler near-surface temperatures, low salinity, higher turbidity and elevated nutrient concentrations (Fig. 2). The response of the turbidity index relative to distance from the nearest glacier runoff source was similar across sites and short-lived compared to other properties such as stratification or temperature, which continued to be affected up to 20-30 km downstream. The more rapid decline in turbidity was observed because sediment settled out of near-surface waters relatively quickly whereas freshwater is buoyant and therefore remained at the surface for a much longer time, and continued to cool surface waters further downstream as well. Beyond $10 \mathrm{~km}$, differences in temperature gradients were observed among study regions, with highest distal temperatures in IBYAK, intermediate distal temperatures in PWS and lowest distal temperatures in GLBA. Lower near-surface temperatures and higher nutrient indices in GLBA downstream from glacier 

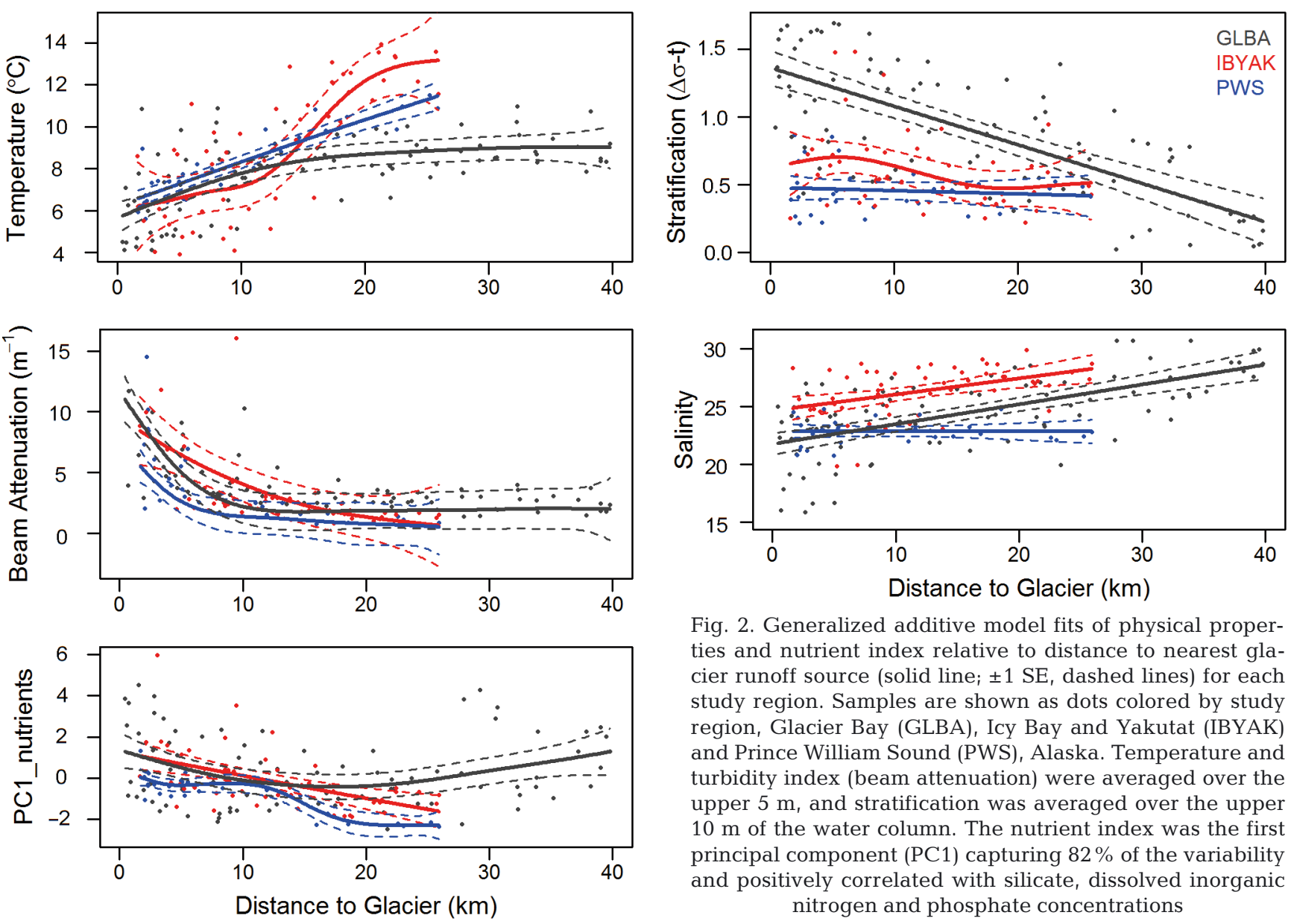

Fig. 2. Generalized additive model fits of physical properties and nutrient index relative to distance to nearest glacier runoff source (solid line; $\pm 1 \mathrm{SE}$, dashed lines) for each study region. Samples are shown as dots colored by study region, Glacier Bay (GLBA), Icy Bay and Yakutat (IBYAK) and Prince William Sound (PWS), Alaska. Temperature and turbidity index (beam attenuation) were averaged over the upper $5 \mathrm{~m}$, and stratification was averaged over the upper $10 \mathrm{~m}$ of the water column. The nutrient index was the first principal component (PC1) capturing $82 \%$ of the variability and positively correlated with silicate, dissolved inorganic nitrogen and phosphate concentrations

runoff sources were driven mainly by the presence of shallow marine sills where upwelling and mixing of cooler, nutrient-rich deep water occurs (Etherington et al. 2007). The relationship between stratification and distance to glacier runoff source was linear in GLBA and sigmoidal in IBYAK. Salinity response to glacier distance was linear in GLBA and IBYAK. There was no relationship between stratification or salinity with increasing glacier distance detected in PWS (Fig. 2), reflecting both weaker stratification near the glaciers and limited sampling distance compared to other regions. Stratification and salinity were influenced by complexity of fjord topography and bathymetry, whereby long, narrow fjords isolated by shallow marine sills (e.g. Harriman Fjord in PWS, Icy Bay in IBYAK and Muir Inlet in GLBA) had greater stratification and lower salinity farther from glacier sources than fjords without sills (e.g. College Fjord in PWS and the west arm of GLBA), or areas with more direct oceanic influence (e.g. Yakutat Bay in IBYAK, Fig. 3). Hubbard Glacier, a tidewater gla-

cier near the head of Yakutat Bay, had less influence on stratification and salinity than runoff from the piedmont Malaspina Icefield draining into the bay.

In IBYAK higher nutrient concentrations were observed near Malaspina Icefield outflows and tidewater glaciers at the head of the Bays (Fig. 4). In Yakutat Bay high nutrient concentrations were also sampled over shallow glacier-carved bottom features near the center of the Bay (Fig. 1). Likewise, in GLBA high nutrient concentrations were observed over the shallow marine sill at the entrance to the main bay as a result of strong tidal mixing of deep marine nutrients over a complex bathymetry and constricted passageway (Table 1, Fig. 4; Etherington et al. 2007, Hill et al. 2009). In PWS nutrient concentrations were lowest at the southern end of the fjord away from glacier runoff sources (Fig. 4). Low N:Si ratios (Table 1) suggest silicate is not limiting phytoplankton in glacial fjords (Gilpin et al. 2004), and average N:P ratios were below the Redfield ratio of 16:1 (Redfield 1958) particularly in PWS (Table 1). The highly stratified 

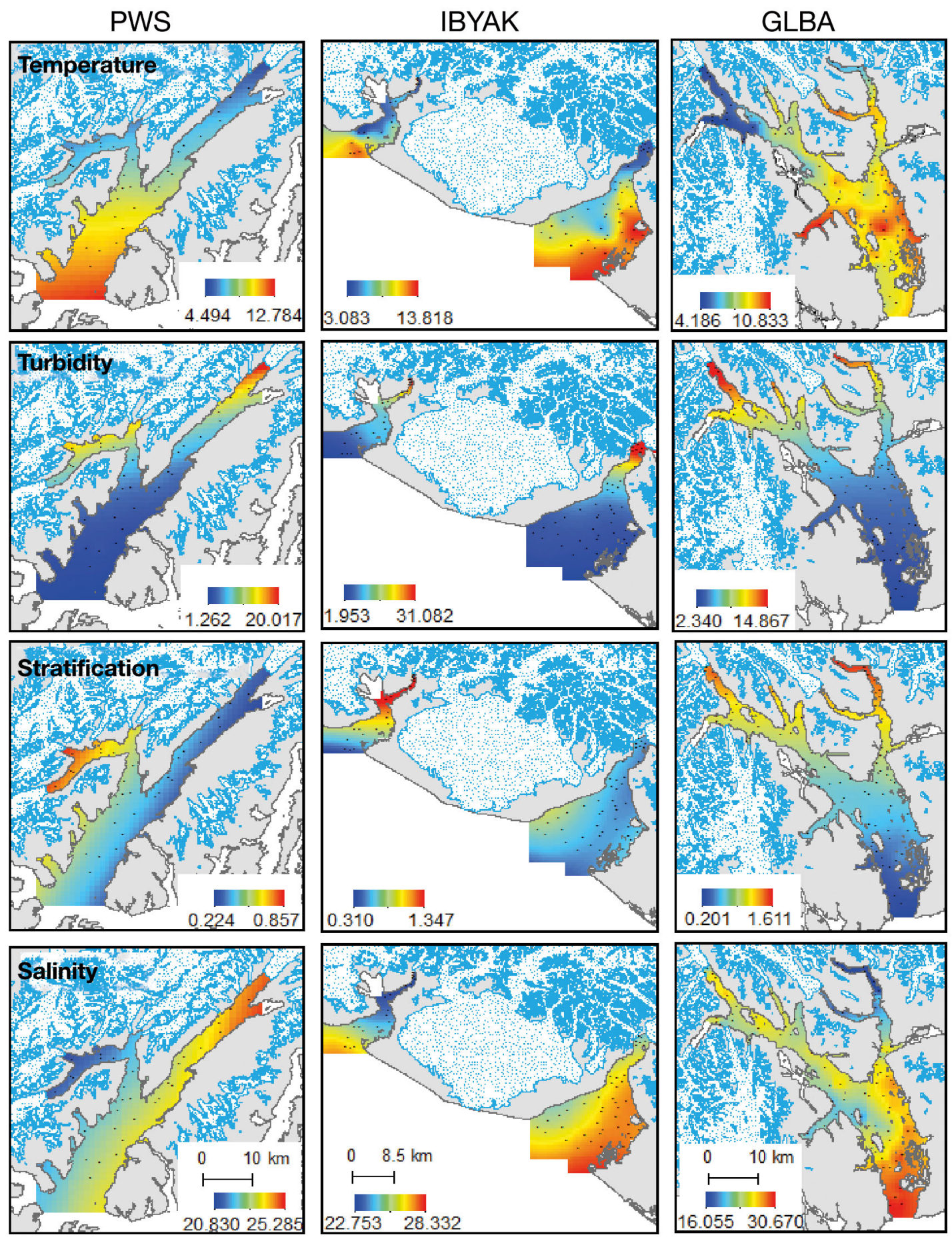

Fig. 3. Detrended ordinary kriging predictions of temperature $\left({ }^{\circ} \mathrm{C}\right)$, turbidity index (beam attenuation, $\left.\mathrm{m}^{-1}\right)$, stratification $(\Delta \sigma-\mathrm{t})$ and salinity in glacial fjords of the Gulf of Alaska during summer. PWS: Prince William Sound; IBYAK: Icy Bay and Yakutat Bay; GLBA: Glacier Bay. Note differing scales among study regions sampled in different years

waters near the head of Muir Inlet differed markedly from the west arms of GLBA and fjord systems in other study regions. Most glaciers in Muir Inlet are land-terminating except for one tidewater glacier that is separated from the inlet by a proglacial basin.
Thirteen stations sampled closest to the head of Muir Inlet had above average chl a concentrations that corresponded with lower $\mathrm{N}: \mathrm{P}$ ratios (mean $\mathrm{SE}=$ $3.81 \pm 0.53)$ and relatively elevated $\mathrm{SiOH}_{4}$ concentrations (mean $\mathrm{SE}=11.93 \pm 1.09 \mu \mathrm{M}$ ). Elevated concen- 

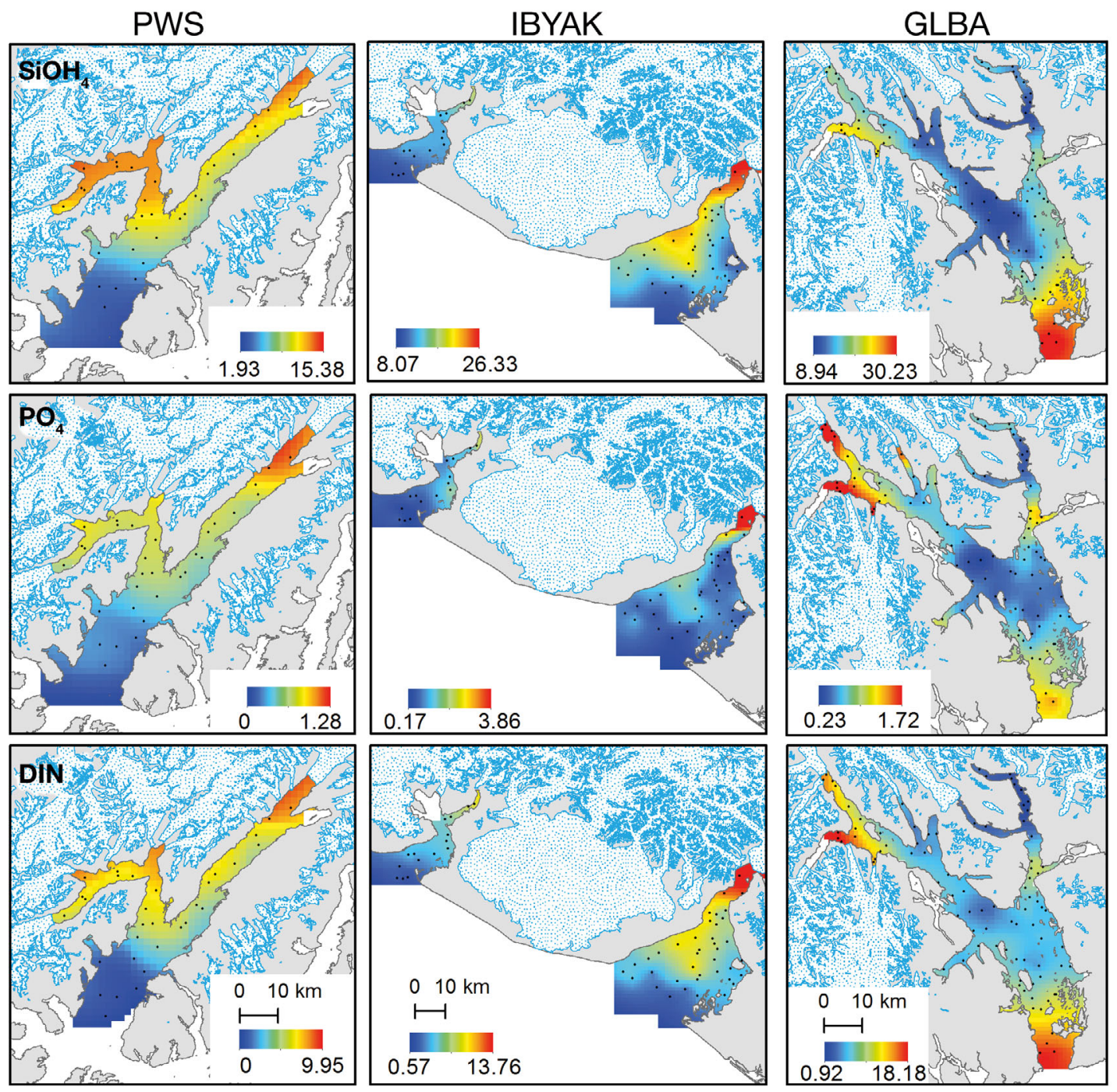

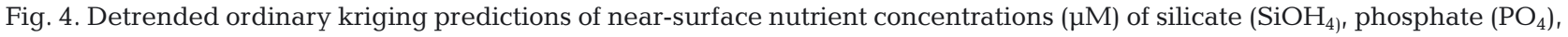
and dissolved inorganic nitrogen (DIN) in glacial fjords of the Gulf of Alaska during summer. PWS: Prince William Sound; IBYAK: Icy Bay and Yakutat Bay; GLBA: Glacier Bay. Note differing scales among study regions sampled in different years

trations of $\mathrm{NO}_{3}$ were observed near tidewater glaciers in the West Arm $(12.50 \pm 0.84 \mu \mathrm{M}, \mathrm{n}=12)$, where subglacial melt water causes upwelling of nutrient rich waters. Similarly, high $\mathrm{NO}_{3}$ concentrations were observed at the shallow sill near the entrance to GLBA $(12.80 \pm 1.25 \mu \mathrm{M}, \mathrm{n}=7)$ where waters are mixed by strong tidal currents (Fig. 4; Hill et al. 2009). Conditions in the West Arm and entrance sill of GLBA were more representative of nitrogen renewal from upwelled marine sources.

\section{Chl a}

The lowest chl a concentrations occurred within the turbid glacier plume waters, and within PWS in general (Table 1, Fig. 5). Lower quantile values of chl a concentrations were also observed near constricted passages and over shallow marine sills, for example at the southern entrance of GLBA and Disenchantment Bay near the head of YAK (Fig. 5).

The first 2 principal components (PC1_glacier and PC2_glacier) captured $80 \%$ of the variability in nutrients, turbidity, temperature and stratification. The different nutrients loaded similarly to one another along PC1 (0.44-0.48), while PC1_glacier loadings for turbidity and temperature had opposite signs to one another $(0.39,-0.45$, respectively). Stratification loaded strongly on PC2_glacier (0.75), suggesting that it varies independently of the glacial gradient defined by nutrients, turbidity and temperature. Residuals from an OLS regression of chl a on PC1 

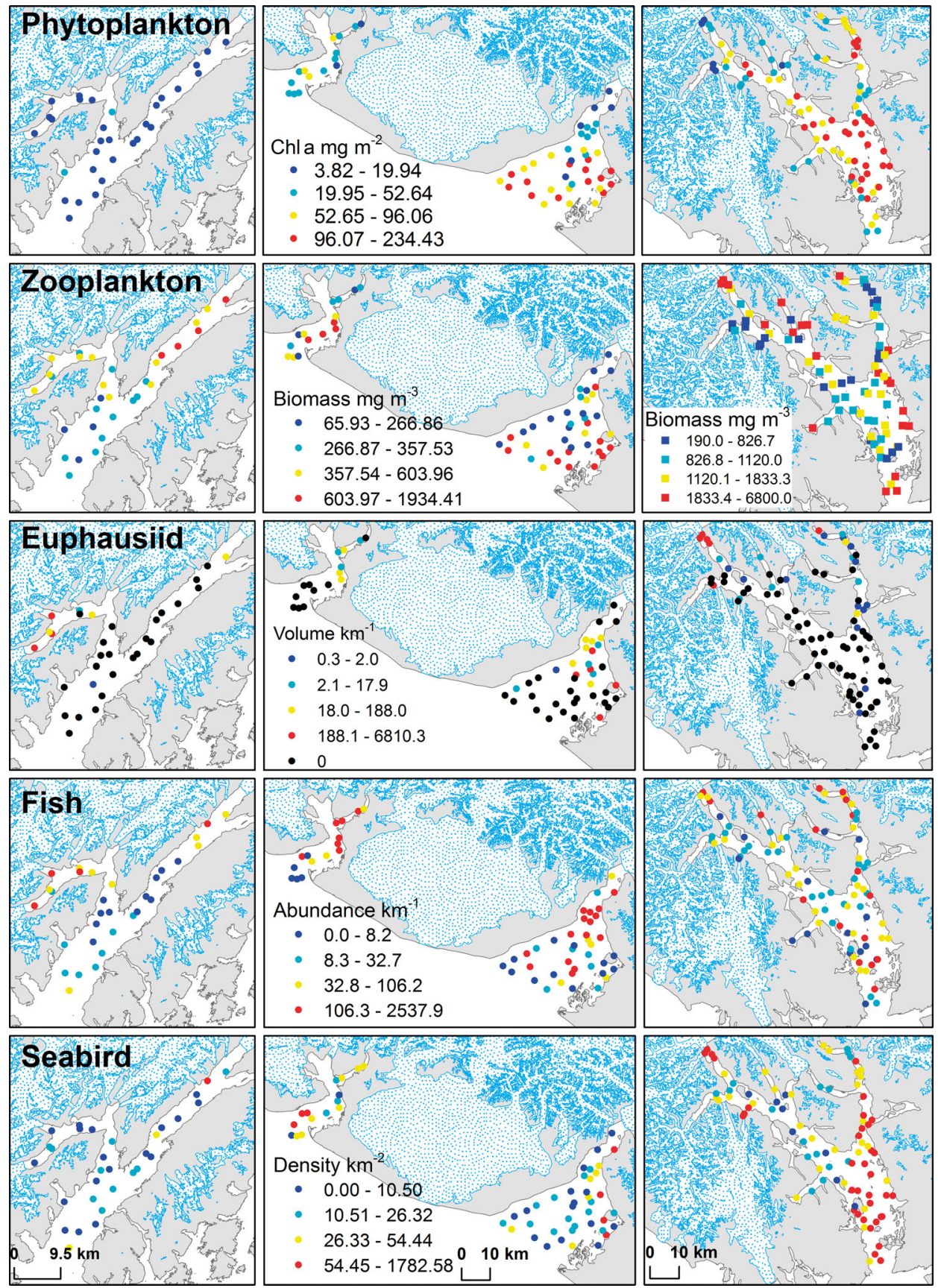

Fig. 5. Quantile map of trophic components measured in Prince William Sound (left), Icy Bay and Yakutat Bay (middle) and Glacier Bay (right), Alaska. Glacier ice is shown in blue stipple. Processing methods for zooplankton biomass in Glacier Bay (squares) differed from samples in other study regions (circles). Euphausiid volume and fish abundance in trawls was standardized by distance towed $(\mathrm{km})$. Only pelagic-feeding (fish and zooplankton) marine birds sighted on the water were included in the seabird density index

glacier, PC2_glacier and study region had significant spatial autocorrelation (Moran's I test, $\mathrm{p}<0.05)$. The AIC-best GLS model (LRT: p < 0.001) included an exponential correlation structure and explained $67 \%$ of the variability in chl $a$ using PC1 and study region as predictors (Table 2 ).
Chl a concentrations were lower in PWS compared to other study regions (Table 2). A negative relationship between chl a concentrations and PC1_glacier indicated decreasing chl a concentration with increasing nutrients, higher turbidity and lower temperatures (Table 2, Fig. 6). 
Table 2. Summary of results from regressions of ecosystem components as a function of predictors sampled in glacier fjords in the Gulf of Alaska. OLS: ordinary least squares; GLS: generalized least squares; GLM: generalized linear model; GLBA: Glacier Bay; IB: Icy Bay; YAK: Yakutat; IBYAK: combined IB and YAK; PWS: Prince William Sound

\begin{tabular}{|c|c|c|c|c|c|c|}
\hline Ecosystem component & Model & Predictor & Coefficient & SE & $t$ & $\mathrm{p}$ \\
\hline \multirow[t]{4}{*}{ Chl a $\left(r^{2}=0.67\right)$} & \multirow[t]{4}{*}{ GLS } & PC1_glacier & -0.154 & 0.017 & -9.161 & $<0.001$ \\
\hline & & Study region GLBA & 0.247 & 0.108 & 2.288 & 0.023 \\
\hline & & Study region IBYAK & -0.208 & 0.165 & -1.263 & 0.208 \\
\hline & & Study region PWS & -1.200 & 0.193 & -6.226 & $<0.001$ \\
\hline \multirow[t]{5}{*}{ Copepod Biomass $\left(r^{2}=0.27\right)$} & \multirow[t]{5}{*}{ OLS } & Ammonium concentration (all regions) & 0.214 & 0.079 & 2.711 & 0.008 \\
\hline & & Study region IBYAK & -2.961 & 0.660 & -4.488 & $<0.001$ \\
\hline & & Study region PWS & 3.766 & 1.109 & 3.396 & 0.001 \\
\hline & & Temperature IBYAK & 0.394 & 0.091 & 4.317 & $<0.001$ \\
\hline & & Temperature PWS & -0.550 & 0.153 & -3.606 & 0.001 \\
\hline \multirow[t]{3}{*}{ Euphausiid presence/absence } & \multirow[t]{3}{*}{ GLM } & Gelatinous Zooplankton (GZ) & -0.299 & 0.082 & -3.667 & $<0.001$ \\
\hline & & Turbidity & 1.348 & 0.313 & 4.310 & $<0.001$ \\
\hline & & GZ-Turbidity interaction & 0.289 & 0.101 & 2.868 & 0.004 \\
\hline \multirow[t]{3}{*}{ Fish CPUE PWS $\left(r^{2}=0.48\right)$} & \multirow[t]{3}{*}{ GLS } & $\mathrm{GZ}$ & -0.458 & 0.228 & -2.009 & 0.055 \\
\hline & & Turbidity & 1.881 & 0.502 & 3.748 & $<0.001$ \\
\hline & & GZ-Turbidity interaction & -0.664 & 0.237 & -2.802 & 0.009 \\
\hline \multirow[t]{3}{*}{ Fish CPUE IBYAK $\left(\mathrm{r}^{2}=0.43\right)$} & \multirow[t]{3}{*}{ OLS } & GZ & -0.327 & 0.084 & -3.901 & $<0.001$ \\
\hline & & Turbidity & 0.855 & 0.604 & 1.415 & 0.163 \\
\hline & & GZ-Turbidity interaction & 0.268 & 0.121 & 2.213 & 0.031 \\
\hline \multirow[t]{3}{*}{ Fish CPUE GLBA $\left(\mathrm{r}^{2}=0.17\right)$} & \multirow[t]{3}{*}{ OLS } & GZ & -0.156 & 0.112 & -1.397 & 0.166 \\
\hline & & Turbidity & 0.782 & 0.251 & 3.117 & 0.003 \\
\hline & & GZ-Turbidity interaction & 0.146 & 0.152 & 0.957 & 0.341 \\
\hline \multirow[t]{10}{*}{ Seabird Density $\left(r^{2}=0.42\right)$} & \multirow[t]{10}{*}{ GLS } & Silica (all regions) & 0.065 & 0.017 & 3.872 & $<0.001$ \\
\hline & & Forage fish biomass (all regions) & 0.089 & 0.043 & 2.051 & 0.042 \\
\hline & & Fjord GLBA & -1.219 & 1.617 & -0.754 & 0.452 \\
\hline & & Fjord IB & 0.122 & 2.391 & 0.051 & 0.959 \\
\hline & & Fjord PWS & 0.993 & 2.165 & 0.459 & 0.647 \\
\hline & & Fjord YAK & -6.312 & 1.999 & -3.157 & 0.002 \\
\hline & & Temperature GLBA & 0.104 & 0.229 & 0.452 & 0.652 \\
\hline & & Temperature IB & -0.045 & 0.338 & -0.134 & 0.894 \\
\hline & & Temperature PWS & -0.247 & 0.300 & -0.824 & 0.411 \\
\hline & & Temperature YAK & 0.755 & 0.291 & 2.591 & 0.010 \\
\hline
\end{tabular}

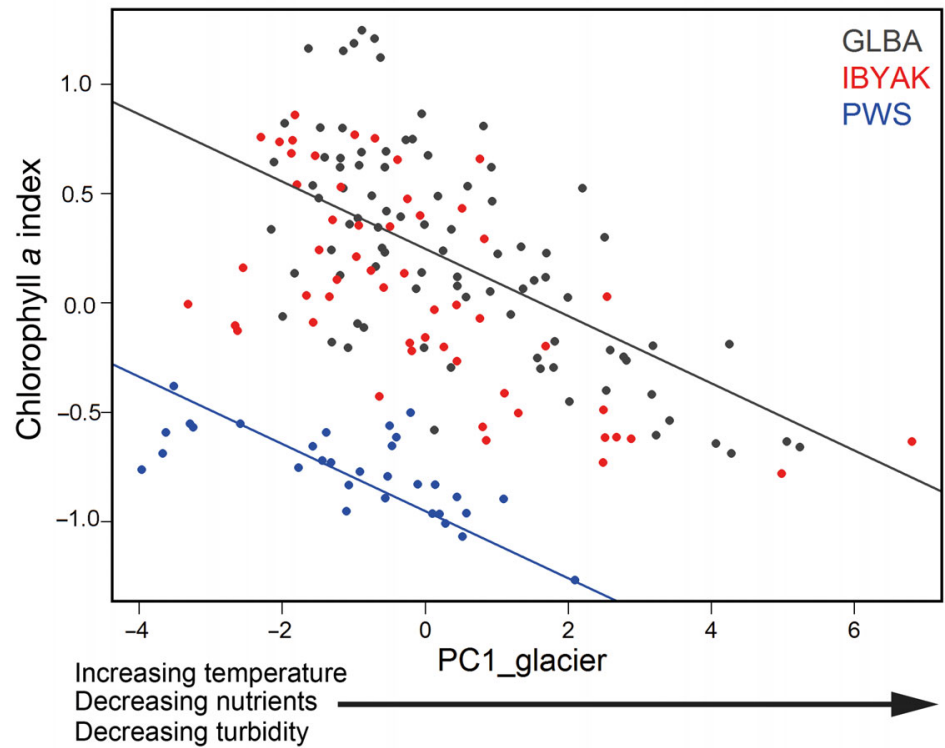

Fig. 6. Study region specific linear relationships (lines) between chl $a$ index (fourth-root transformed chl a concentrations anomaly, $\mathrm{mg} \mathrm{m}^{-2}$ ) and the first principal component (PC1_glacier) describing variability of glacially modified gradients in Gulf of Alaska coastal fjords. Model results indicated that intercepts for GLBA and IBYAK were not significantly different from one another (Table 2), hence regression line for IBYAK is not shown. Based on PCA loadings of glacially modified gradients, increasing values of PC1_glacier (arrow) indicate increasing temperature, decreasing nutrients and decreasing turbidity. PWS: Prince William Sound; IBYAK: Icy Bay and Yakutat Bay; GLBA: Glacier Bay 


\section{Zooplankton}

Zooplankton biomass estimates from plankton tows (all species combined) were higher near glaciers at the head of fjords in the more protected study regions with greater estuarine influence (i.e. GLBA and PWS), but lower near glaciers at the heads of fjords at the more oceanic study region (IBYAK) (Fig. 3). In GLBA zooplankton biomass was patchy, but higher quantiles were generally observed adjacent to tidewater glaciers, over the sill at the entrance to the Bay, and in the shallow reaches of the eastern shore.

BRT analysis indicated ammonium and temperature were the best predictors of copepod biomass in PWS and IBYAK (Table 2). The AIC best-fit model included ammonium and an interaction between temperature and study region (OLS R $\mathrm{R}^{2}=0.27, \mathrm{p}<0.001$ ).

Copepod biomass (sampled in IBYAK and PWS only) was positively associated with temperature at IBYAK and negatively associated with temperature at PWS. In both study regions higher copepod biomass was coincident with higher ammonium concentrations.

\section{Euphausiids}

CPUE of euphausiids was highest in near-surface waters adjacent to glaciers (Fig. 5). In IBYAK they also occurred near Malaspina Glacier outflows and near marine sills in both bays. They were generally absent at the shallow trawl depths away from glacier runoff sources. BRT analysis on presence/absence data indicated temperature, turbidity and gelatinous zooplankton had high relative influence on euphausiid presence.

Euphausiid occurrence in near-surface trawls was positively associated with high turbidity and low gelatinous zooplankton abundance (Table 2). An interaction between these variables was significant because euphausiids also occurred in waters with low turbidity and low gelatinous zooplankton in Yakutat Bay (Figs. 3 \& 5), which may have been mediated by currents or upwelling at this study region. This model predicted euphausiid occurrence accurately for $77 \%$ of observations.

\section{Fish}

Fish abundance in trawl catches was high near tidewater glacier outflows, and near submerged sills that demarcate previous positions of glacier termini
(Fig. 5). Large catches also occurred in areas of low turbidity away from glacial influence in Yakutat Bay and Glacier Bay. A simple index of proximity to glacial outflow, i.e. the proportion of the total catch for a given species within $10 \mathrm{~km}$ of a glacier runoff source ( $44 \%$ of stations in GLBA, $48 \%$ of stations in IBYAK and $61 \%$ of stations in PWS), revealed which fish species were more likely to occur in glacially modified habitats (Table 3).

For example, young-of-the-year fish, including walleye pollock, capelin and herring, dominated trawl catches (Table 3). Immature and spawning capelin, adult pollock and euphausiids were important in catches within $10 \mathrm{~km}$ of glaciers. In IBYAK and GLBA large catches of capelin were observed far from glaciers as well (Table 3). The typically mesopelagic northern lampfish was relatively abundant in shallow glacial waters in GLBA, and longfin smelt were observed only in IBYAK. Pacific sand lance were most abundant in areas without glacial influence in GLBA, and they were rare or absent from catches in IBYAK and PWS (Table 3). Gelatinous zooplankton volume was lowest in IBYAK, and the greatest proportion of the total catch by fish species was observed $>10 \mathrm{~km}$ from tidewater glaciers in all study regions (Table 3). BRT analysis indicated turbidity, gelatinous zooplankton and the interaction between these variables had a strong influence on fish abundance (Table 4).

Fish abundance was significantly related to gelatinous zooplankton volume and turbidity at all 3 sites. Due to limited overlap of these variables among sites and a difficult interpretation of a 3-way interaction among site, gelatinous zooplankton and turbidity, we ran separate regressions for each site. Still, the response of fish CPUE to gelatinous zooplankton and turbidity at all sites was similar (Table 2). The interaction between gelatinous zooplankton and turbidity suggested that fish were more abundant in turbid waters with low gelatinous zooplankton catch, while fish abundance was lowest in clear water or where gelatinous zooplankton were more abundant (PWS: GLS, $\mathrm{R}^{2}=0.48$; IBYAK: OLS, $\mathrm{R}^{2}=0.43, \mathrm{p}<0.001$, and GLBA: OLS, $\mathrm{R}^{2}=0.20, \mathrm{p}<0.001$, Table 2, Fig. 5).

\section{Seabirds}

The pelagic-feeding marine bird community was dominated by black-legged kittiwakes, marbled and Kittlitz's murrelets, and glaucous-winged gulls. Overall, marine bird densities were highest in GLBA compared to other study regions (Tables 1 \& 3, Fig. 3). 


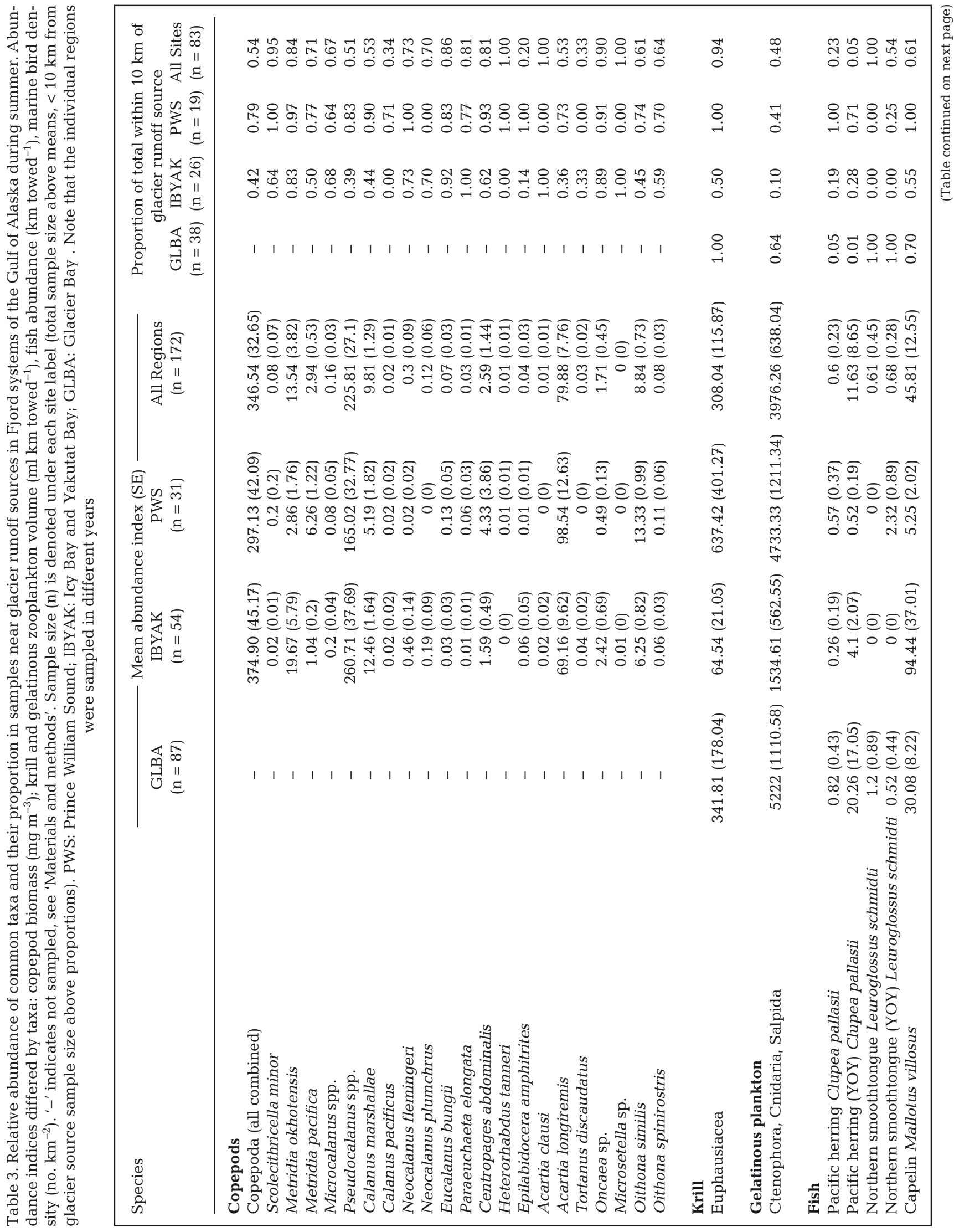




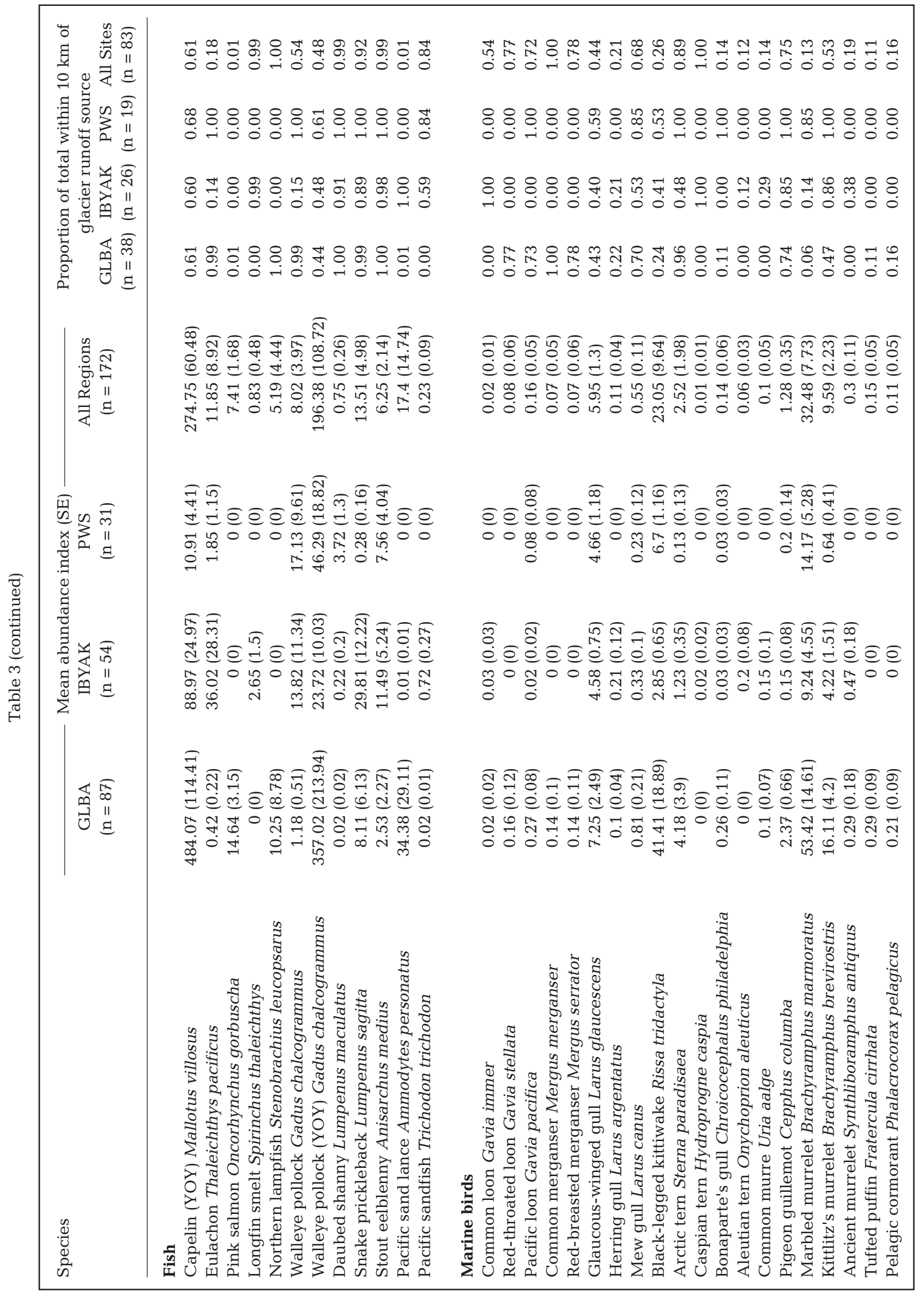


Table 4. Boosted regression tree results, including model outputs (see Elith et al. 2008) and relative influence (\%) of each predictor variable for lower (copepod), middle (euphausiids, fish), and upper (marine bird) trophic level responses to physical and biological habitat variables. Prey indices, study region, variables with relative influence $>10 \%$ and interactions (indicated by asterisks) were used as predictors (in bold) in parametric models (see Table 2). $0 / 1$ indicates presence/absence; ' - ' indicates the variable was not included in the model (see 'Materials and methods')

\begin{tabular}{|c|c|c|c|c|}
\hline & Copepods & $\begin{array}{c}\text { Euphausiids } \\
(0 / 1)\end{array}$ & Fish & $\begin{array}{l}\text { Marine } \\
\text { birds }\end{array}$ \\
\hline \multicolumn{5}{|l|}{ Model outputs } \\
\hline Tree complexity & 5 & 2 & 4 & 2 \\
\hline No. of trees & 3550 & 2700 & 1700 & 5800 \\
\hline Model residual deviance & 0.28 & 0.74 & 1.45 & 0.40 \\
\hline CV deviance (SE) & $0.54(0.06)$ & $1.03(0.07)$ & $2.33(0.23)$ & $0.78(0.11)$ \\
\hline Training data correlation & 0.81 & 0.76 & 0.78 & 0.85 \\
\hline \multicolumn{5}{|c|}{ Relative influence of variables } \\
\hline Study region & $0.21^{*}$ & 0 & 0.58 & 2.33 \\
\hline Fjord & 0.46 & 0.18 & 0.45 & $12.47^{*}$ \\
\hline Chlorophyll a & $6.35^{*}$ & 3.36 & 2.75 & 3.27 \\
\hline Ammonium & $17.41^{*}$ & 3.89 & 3.3 & 4.66 \\
\hline Nitrite & 5.54 & 2.7 & 6.41 & 3.4 \\
\hline Nitrate & 5.8 & 4.24 & 3.31 & 3.65 \\
\hline Silica & 7.17 & 5.23 & 5.09 & $12.15^{*}$ \\
\hline Phosphate & 3.8 & 3.58 & 3.35 & 2.33 \\
\hline Temperature (ave. $50 \mathrm{~m}$ ) & $12.59^{*}$ & 16.6 & 4.5 & $11.29^{*}$ \\
\hline Salinity (ave. $50 \mathrm{~m}$ ) & 6.94 & 4.85 & 1.82 & 2.25 \\
\hline Turbidity Index (ave. 15 m) & 5.4 & 22.6 & 3 & 2.03 \\
\hline Stratification & 5.07 & 1.06 & 2.98 & 4.06 \\
\hline Glacier area within $10 \mathrm{~km}$ & 3.64 & 2.01 & 0.89 & 0.54 \\
\hline Bottom depth & 5.43 & 2.9 & 5.5 & 2.43 \\
\hline Distance from shore & 2.75 & 1.37 & 3.06 & 3.87 \\
\hline Photic depth & 2.86 & 6.12 & 1.46 & 1.35 \\
\hline Distance to glacier & 3.7 & 4.15 & 4.18 & 9.6 \\
\hline Zooplankton biomass & - & 1.93 & 2.76 & 2.98 \\
\hline Gelatinous zooplankton CPUE & - & 11.78 & $14.89^{*}$ & 5.47 \\
\hline Euphausiid CPUE & - & - & 7.23 & 0.88 \\
\hline Forage fish biomass & - & - & & 8.9 \\
\hline
\end{tabular}

Seabird at-sea densities may have been underestimated in PWS and IBYAK because we sampled towards the end of the breeding cycle when chicks begin to fledge and adults disperse because they are less tied to the nesting areas, although timing of breeding phenology may differ among years (Arimitsu et al. 2011). BRT analysis revealed high relative influence of fish biomass, silicate, temperature and fjord variables on seabird density (Table 4). Glacier distance was also important but was strongly correlated with other predictors so was not used in the regression analysis. We also explored models that contained interactions between silicate, fjord (i.e. allowing differences between IB and YAK in addition to other study regions) and temperature as identified in the BRT analysis (not shown).

The most parsimonious seabird density model included silicate, forage fish biomass, and temperature by fjord (GLS R $\mathrm{R}^{2}=0.43, \mathrm{p}<0.001$; Table 2). Higher density was observed with increasing silicate levels and increasing forage fish biomass. Higher seabird densities were associated with higher temperatures in YAK, but the slope of the linear relationship between seabird density and temperature was not significantly different from zero in GLBA, IB or PWS (Table 2).

\section{DISCUSSION}

Similar to work in other high-latitude fjords systems throughout the world (Burrell 1988, Gibbs et al. 2000, Hop et al. 2002, Silva et al. 2011), we found that glacial runoff modified near-surface habitat gradients in turbidity, temperature, stratification and nutrients and these effects were strongest up to $10 \mathrm{~km}$ away from glacier freshwater sources. The distributions of phytoplankton and higher trophic level predators were influenced by glacially modified physical and nutrient gradients in addition to biologically important indices like prey availability (Table 2). Likewise, research in the Antarctic found that enriched terrigenous input from glacial melt water was associated with densities of phytoplankton, zooplankton and pelagic seabirds (Smith et al. 2007). The insights gained from our integrated ecosystem approach generally concur with previous work in glacial fjords that focused on individual ecosystem components such as sedimentation and hydrographic processes (Syvitski 1989, Gay \& Vaughan 2001), phytoplankton (Etherington et al. 2007, Piwosz et al. 2009), and higher trophic level organisms in glacially active coastal fjords (Arimitsu et al. 2012, Renner et al. 2012, Lydersen et al. 2014, Grémillet et al. 2015). In these studies and ours, glacialmarine ecosystems around the world are highly structured by runoff at spatial scales of $10 \mathrm{~s}$ of $\mathrm{km}$.

\section{Fjord ecosystem response to glacial runoff}

Near-surface nutrient concentrations were often greatest near glacial outflows, especially in the turbid tidewater glacier runoff plumes where nutrient 
demand by primary producers was low. A negative relationship between chl a and glacially modified gradients (i.e. high nutrients, low temperature, high stratification and high turbidity; Table 2, Fig. 6) suggests nutrient depletion occurs at the highest chl $a$ concentrations where lower turbidity allows greater light penetration into the water column. Nutrient depletion associated with high chl a concentrations during productivity blooms was also reported from fjords in Greenland (Juul-Pedersen et al. 2015). Nutrient data were consistent with previous work that shows glacier runoff contains elevated levels of rock-derived elements such as silicate and phosphate (Hood \& Scott 2008). Freshwater sources of nitrogen can be highest in moderately glaciated watersheds dominated by early successional, nitrogen-fixing vegetation (Hood \& Scott 2008), however concentrations of upwelled marine sources of nitrogen may exceed those of freshwater sources (Burrell 1988). Moreover, work by Juul-Pedersen et al. (2015) suggests that estuarine circulation resulting from glacier runoff during the melt season causes upwelled marine nutrients to stimulate primary production near sills in Greenland fjords.

We observed opposite patterns of zooplankton distribution relative to glacier freshwater influence in protected vs. oceanic bays and fjords (Fig. 5). Higher copepod biomass was associated with cooler temperatures near glaciers at the head of fjords in the most protected study region (PWS), but in warmer waters far from glacier runoff in the study region most exposed to open ocean (YAK). Zooplankton excrete ammonia (Ikeda \& Motoda 1978) thus the positive relationship between these variables was not surprising (Table 2). Overall, however, our models explained relatively little of the variability in copepod biomass (PWS and IBYAK only), which is likely influenced by factors we did not measure such as subsurface advection into the fjords associated with estuarine circulation (Burrell 1988, Mueter et al. 2009). The negative relationship between copepod biomass and temperature in PWS, the study region with lowest mean salinity in the upper $50 \mathrm{~m}$ of the water column (Table 1), suggests advection towards the head of the fjord is an important factor in their relatively higher abundance there. Basedow (2004) found advective gain of neritic copepod species and stages into fjords in Svalbard is related to fjord topography and sill depth. High zooplankton biomass at both ends of the glacier-induced habitat gradients is suggestive of differing processes affecting plankton dynamics in freshwater vs. marine regions. This has been previously shown through differing zooplankton produc- tivity cycles in glacial vs. non-glacial areas of GLBA (Robards et al. 2003).

We documented a positive response of euphausiids and planktivorous fish (e.g. walleye pollock and capelin) to high turbidity conditions and the scarcity of gelatinous zooplankton within the glacier plume waters in all of the fjords systems we examined (Fig. 5). The co-occurrence of euphausiids and planktivorous fish in the inner fjords is consistent with work in other tidewater glacier fjords (Dalpadado et al. 2016) and may be explained by predatorprey dynamics in the presence of high turbidity. Laboratory studies suggest that high turbidity reduces light intensity, enhances feeding opportunities (more zooplankton food) and reduces predation pressure (fewer possible consumers) for planktivorous fish (De Robertis et al. 2003). The positive relationship between fish abundance and turbidity has been documented in estuaries elsewhere (Blaber \& Blaber 1980, Emmett et al. 2006). Both euphausiid (presence/absence) and fish abundance indices were negatively associated with gelatinous zooplankton abundance in trawl catches. Our results are supported by long-term data which suggest higher abundances of jellyfish are associated with warmer temperatures and lower abundance of forage fish competitors (Brodeur et al. 2002, Purcell 2005). Although net avoidance by faster-swimming fish in clear water during daylight hours may have contributed to variability in catch composition (Blaxter \& Parrish 1965, Williams et al. 2015) and thus confounded our differential catch rates in turbid vs. clear waters, the consistent observation that all 3 taxa (i.e. slow-moving euphausiid and gelatinous zooplankton as well as faster moving fish) exhibited similar catch patterns across all study regions (Table 2) suggests it was not simply due to net avoidance by visually oriented fish.

A positive relationship between seabirds and forage fish biomass across the fjords we examined was not surprising given the high energetic demands of breeding marine birds (Cury et al. 2011) and their strong tendency to aggregate around prey schools at sea (Piatt et al. 2007). Less intuitively, our data indicated that silicate, an inorganic nutrient of no direct use to seabirds, was an important predictor of seabird distribution. Riverine sources provide roughly $80 \%$ of the available silicate to the world's oceans (Tréguer et al. 1995), and silicate is an important component of the marine biogeochemical cycle particularly with regards to the growth of diatoms (Pichevin et al. 2014). In glacial fjords chemical weathering of rock and riverine sources supply high levels of dissolved silicate to fjord waters. Thus silicate is probably not a 
limiting nutrient for primary production (mainly diatoms) in the fjords. Further, it's unlikely that the seabird-silicate relationship was due to an indirect trophic linkage mediated by phytoplankton because the influence of chl a on marine bird density was relatively low (Table 4).

An alternate explanation for the relationship between seabird density and silicate concentrations is that unused silicate in the near-surface waters may serve as a proxy for frontal regions or upwelling, both of which are known to aggregate prey and attract marine bird and mammal predators (Ainley et al. 2005). In glacial fjord systems, vertical mixing of lowdensity water may occur near submerged glacial discharge and calving glacier faces (Bartholomaus et al. 2013), and upwelling of high-density water may occur in frontal regions over marine sills through constricted passages (Svendson 1986). Our data suggests silicate may be a better indicator of upwelling than seawater density in fjords with strong melt water-induced environmental gradients.

\section{Comparison of glacial fjord ecosystems}

Similarities among the fjords we sampled could be traced to the unifying influence of glacial runoff during the summer melt season. Common in surface waters of all fjords were the conditions of high turbidity and low phytoplankton stocks in the glacial runoff plume. Euphausiids, spawning capelin, adult walleye pollock, snake pricklebacks and stout eelblennies commonly occurred in the dispersed marine scattering layer of the upper water column near tidewater glaciers (Table 3). Seabird species well-adapted to turbid foraging conditions in the glacier plume, such as Kittlitz's murrelets, black-legged kittiwakes and Arctic terns were observed feeding on euphausiids brought to the surface during calving events and were also abundant in the glacial plume areas (Table 3, Arimitsu et al. 2012). Osmotic shock from freshwater may also enhance foraging opportunities for seabird predators (Lydersen et al. 2014) by causing euphausiid mortality near tide-water glaciers (Zajaczkowski \& Legeżyńska 2001).

Whereas similarities among fjords were due to environmental gradients caused by glacial runoff, differences among study regions were due in part to differing topographic complexities (e.g. steep shallow sills marking previous glacier termini, constricted fjord passageways, adjoining inside waters vs. open ocean) that modify sediment, salinity and nutrient distribution in concert with strong tidal cur- rents (Svendson 1986, Syvitski 1989, Hill et al. 2009). High and sustained chl a standing stocks from spring through fall months has been documented in GLBA (Etherington et al. 2007), and this is most likely due to nutrient replenishment from freshwater sources, and to a larger extent, to upwelling over sills and through constricted passageways after the initial spring bloom period. In contrast, owing to nutrient depletion following the light-induced spring bloom, southcentral Alaska and offshore areas adjacent to PWS undergo $2 \mathrm{chl}$ a peaks in spring and fall, with lower chl a standing stocks through June and July (Childers et al. 2005, Strom et al. 2006, Waite \& Mueter 2013).

Although the single 'snapshot' approach we used limited our ability to assess temporal variability as a contributing factor to the ecological patterns we observed, many of the spatial patterns we identified are likely to be representative of these systems during the peak melt season. For example, long-term data on physical conditions and chl a concentrations showed relatively stable spatial patterns in physical variables and persistent chl a peaks through the summer in GLBA, particularly in the central part of the bay (Etherington et al. 2007). Likewise, hydrographic studies in bays and fjords of PWS suggest similar spatial variation due to glacial inputs over time (Gay \& Vaughan 2001). Speckman et al. (2005) documented this well in lower Cook Inlet, where spatial variability in freshwater-induced physical gradients and patterns of community structure persisted in the face of large inter-annual variations in ocean temperature, including the strong 1998 El Niño event. In their discussion, the authors concluded that spatial variability among habitats and community structure far exceeded interannual variability. Indeed, it was the pattern of persistent animal distribution within fjord ecosystems that inspired our search for underlying causal factors, and to compare among fjords. Still, we are unable to rule out the possibility that temporal variability played a role in the differences we observed among study regions. Future work would benefit from a sampling design that facilitates a greater understanding of seasonal and interannual variability among study regions.

\section{Climate change and the future of glacial-marine ecosystems}

Under current climate projections, glaciers will continue to melt across the globe (Jacob et al. 2012, IPCC 2014), and over time glaciers fjords of Alaska 
and other high-latitude systems will transition into non-glacial systems. Glacial and non-glacial fjord systems differ in the volume and timing of freshwater delivery to coastal systems (O'Neel et al. 2015) and also in the thermal structure of plume waters. Drinkwater \& Frank (1994) described freshwater influence on circulation patterns, vertical stability, mixing and nutrient exchange processes and regulation of primary production on coastal ecosystems in non-glacial systems. In glacier fjord systems, estuarine circulation is similarly driven by freshwater runoff, however, a broader and sustained peak in runoff results from tighter coupling to air temperature than is observed in precipitation-dominated systems (Fleming 2005, O'Neel et al. 2015). This basic hydrographic difference results in more stable and prolonged influence of freshwater during the melt season (springsummer) in glacial vs. non-glacial systems.

We anticipate continued changes in the volume and magnitude of glacial runoff will affect coastal marine food webs in the future. Due to the strong structuring effects of turbidity and light penetration into the water column, changes to the influx of glacial sediments will alter the distribution and abundance of phytoplankton, zooplankton and forage fish in the plume waters. The nature of the effects on the biology of coastal ecosystems will depend on the ability of species or communities to tolerate and adapt to changing conditions. Glacial fjords provide important spawning and nursery areas for important forage fish species, and serve as cool-water refugia for species, like capelin, that are dependent on cold water for growth and dispersal (Rose 2005, Arimitsu et al. 2008). Local populations of predators that are associated with diminishing glacial habitats for breeding, such as Kittlitz's murrelets and harbor seals, may experience declines (Kuletz et al. 2003, Kissling et al. 2007, Womble et al. 2010). On the other hand, planktivorous seabirds in Arctic fjords have demonstrated plasticity in their foraging behavior over a wide range of conditions allowing them to maintain fitness under climate warming scenarios (Grémillet et al. 2012).

\section{Conclusion}

Near-surface conditions resulting from glacial runoff underpinned coastal ecosystem structure in fjord ecosystems of the Gulf of Alaska. Phytoplankton are regulated by light and nutrient availability, and both of these factors are modified in coastal waters by influx of freshwater associated with high levels of glacier runoff. Glacially modified habitat gradients influenced the abundance and distribution of plankton, fish and seabirds in these productive coastal ecosystems. Our results agree with studies of Arctic and Chilean fjord ecosystems (Hop et al. 2002, Palma \& Silva 2004, Vargas et al. 2008, Lydersen et al. 2014, Grémillet et al. 2015), pointing to similarities among high-latitude glacier fjord ecosystems worldwide.

The crossroads of glacial runoff and marine influences, as well as tidal interaction with complex fjord geometry, creates productive waters for pelagic communities. Coastal areas in the Gulf of Alaska are important nursery areas for fish, serve as feeding and breeding areas for marine predators, and are of importance to resource managers. Most of Alaska's glaciers are thinning and receding rapidly, and glacier volume loss in the region is expected to increase through the 21st century (Radic et al. 2014, Clarke et al. 2015). We anticipate that continuing changes in volume and timing of glacier runoff will alter the land-to-ocean fluxes of cold glacier freshwater, sediment and nutrients to coastal ecosystems $\left(\mathrm{O}^{\prime} \mathrm{Neel}\right.$ et al. 2015). Our results suggest that future changes in material fluxes from glaciers will affect near-shore marine food webs by altering the physical and biogeochemical structure of fjord ecosystems.

Acknowledgements. This work was possible because of funding and support from the US Geological Survey, Ecosystems Mission Area, Environments Program, Glacier Bay National Park and National Fish and Wildlife Foundation. L. Eisner, N. Hillgruber, G. Eckert, M. Romano, A. Allyn, D. Irons, E. Madison and B. Heflin were instrumental during the planning, data collection and processing phase. We thank captain Greg Snedgen (USGS R/V 'Alaskan Gyre') and Dan Foley (F/V 'Steller') along with their crews. We also appreciate help in the field from J. Douglas, G. Drew, J. King, N. Naslund, L. Nussman, L. Parker, E. Piatt, J. Reum, S. Scott, and K. Weersing. We appreciate comments by L. Etherington (NPS), E. Hood (UAS), A. Beaudreau (UAF) and 3 anonymous reviewers on earlier versions of this manuscript. Use of trade names does not constitute endorsement by the US government.

\section{LITERATURE CITED}

Abookire AA, Piatt JF (2005) Oceanographic conditions structure forage fishes into lipid-rich and lipid-poor communities in lower Cook Inlet, Alaska, USA. Mar Ecol Prog Ser 287:229-240

Ainley DG, Spear L, Tynan C, Barth J, Pierce S, Glennford R, Cowles T (2005) Physical and biological variables affecting seabird distributions during the upwelling season of the northern California Current. Deep-Sea Res II 52: 123-143

Arendt AA, Bliss A, Bolch T, Cogley JG and others (2014) 
Randolph Glacier Inventory - a dataset of global glacier outlines. Version 4.0. Global Land Ice Measurements from Space, Boulder, CO

Arimitsu ML, Piatt JF, Litzow MA, Abookire AA, Romano MD, Robards MD (2008) Distribution and spawning dynamics of capelin (Mallotus villosus) in Glacier Bay, Alaska: a cold water refugium. Fish Oceanogr 17:137-146

Arimitsu ML, Piatt JF, Romano MD, van Pelt TI (2011) Status and distribution of the Kittlitz's murrelet Brachyramphus brevirostris in Kenai Fjords, Alaska. Mar Ornithol 22: 13-22

Arimitsu ML, Piatt JF, Madison EN, Conaway JS, Hillgruber N (2012) Oceanographic gradients and seabird prey community dynamics in glacial fjords. Fish Oceanogr 21: 148-169

Bartholomaus TC, Larsen CF, O'Neel S (2013) Does calving matter? Evidence for significant submarine melt. Earth Planet Sci Lett 380:21-30

Basedow S (2004) Advection of zooplankton in an Arctic fjord (Kongsfjorden, Svalbard). Estuar Coast Shelf Sci 60: 113-124

Blaber SJM, Blaber TG (1980) Factors affecting the distribution of juvenile estuarine and inshore fish. J Fish Biol 17: 143-162

> Blaxter JHS, Parrish BB (1965) The importance of light in shoaling, avoidance of nets and vertical migration by herring. J Cons Int Explor Mer 30:40-57

> Blundell GM, Womble JN, Pendleton GW, Karpovich SA, Gende SM, Herreman JK (2011) Use of glacial and terrestrial habitats by harbor seals in Glacier Bay, Alaska: costs and benefits. Mar Ecol Prog Ser 429:277-290

> Brodeur RD, Sugisaki H, Hunt GL Jr (2002) Increases in jellyfish biomass in the Bering Sea: implications for the ecosystem. Mar Ecol Prog Ser 233:89-103

Burrell DC (1988) Carbon flow in fjords. Oceanogr Mar Biol Annu Rev 26:143-226

> Childers AR, Whitledge TE, Stockwell DA (2005) Seasonal and interannual variability in the distribution of nutrients and chlorophyll a across the Gulf of Alaska shelf: 1998-2000. Deep-Sea Res II 52:193-216

- Clarke GKC, Jarosch AH, Anslow FS, Radic V, Menounos B (2015) Projected deglaciation of western Canada in the twenty-first century. Nat Geosci 8:372-377

Cury PM, Boyd IL, Bonhommeau S, Anker-Nilssen T and others (2011) Global seabird response to forage fish depletion-one-third for the birds. Science 334: 1703-1706

> Dalpadado P, Hop H, Rønning J, Pavlov V and others (2016) Distribution and abundance of euphausiids and pelagic amphipods in Kongsfjorden, Isfjorden and Rijpfjorden (Svalbard) and changes in their relative importance as key prey in a warming marine ecosystem. Polar Biol 39: 1765-1784

De Robertis A, Ryer CH, Veloza A, Brodeur RD (2003) Differential effects of turbidity on prey consumption of piscivorous and planktivorous fish. Fish Sci 1526:1517-1526

$>$ De'ath G (2007) Boosted trees for ecological modeling and prediction. Ecology 88:243-251

Diggle PJ, Ribeiro PJ Jr (2007) Model-based geostatistics. Springer, New York, NY

$>$ Drinkwater KF, Frank KT (1994) Effects of river regulation and diversion on marine fish and invertebrates. Aquat Conserv Freshw Mar Ecosyst 4:135-151

Elith J, Leathwick JR, Hastie T (2008) A working guide to boosted regression trees. J Anim Ecol 77:802-813
Emmett R, Krutzikowsky G, Bentley P (2006) Abundance and distribution of pelagic piscivorous fishes in the Columbia River plume during spring/early summer 1998-2003: relationship to oceanographic conditions, forage fishes, and juvenile salmonids. Prog Oceanogr 68:1-26

Etherington LL, Hooge PN, Hooge ER, Hill DF (2007) Oceanography of Glacier Bay, Alaska: implications for biological patterns in a glacial fjord estuary. Estuaries Coasts 30:927-944

> Fellman JB, Spencer RGM, Hernes PJ, Edwards RT, D'Amore DV, Hood E (2010) The impact of glacier runoff on the biodegradability and biochemical composition of terrigenous dissolved organic matter in near-shore marine ecosystems. Mar Chem 121:112-122

$>$ Fleming SW (2005) Comparative analysis of glacial and nival streamflow regimes with implications for lotic habitat quantity and fish species richness. River Res Appl 21: 363-379

Friedman J (2001) Greedy function approximation : a gradient boosting machine. Ann Stat 29:1189-1232

Gargett AE (1997) The optimal stability 'window': a mechanism underlying decadal fluctuations in North Pacific salmon stocks? Fish Oceanogr 6:109-117

Gay SM, Vaughan SL (2001) Seasonal hydrography and tidal currents of bays and fjords in Prince William Sound, Alaska. Fish Oceanogr 10:159-193

> Gibbs MT, Bowman MJ, Dietrich DE (2000) Maintenance of near-surface stratification in Doubtful Sound, a New Zealand fjord. Estuar Coast Shelf Sci 51:683-704

Gilpin LC, Davidson K, Roberts E (2004) The influence of changes in nitrogen: silicon ratios on diatom growth dynamics. J Sea Res 51:21-35

Gould PJ, Forsell DJ (1989) Techniques for shipboard surveys of marine birds Appendix A. US Fish and Wildlife Service, Anchorage, AK

> Grémillet D, Welcker J, Karnovsky NJ, Walkusz W and others (2012) Little auks buffer the impact of current Arctic climate change. Mar Ecol Prog Ser 454:197-206

Grémillet D, Fort J, Amélineau F, Zakharova E, Le Bot T, Sala E, Gavrilo M (2015) Arctic warming: nonlinear impacts of sea-ice and glacier melt on seabird foraging. Glob Change Biol 21:1116-1123

Harris RP, Wiebe PH, Lenz J, Skjoldal HR, Huntley M (eds) (2000) ICES zooplankton methodology manual. Academic Press, San Francisco, CA

Hill DF, Ciavola SJ, Etherington LL, Klaar MJ (2009) Estimation of freshwater runoff into Glacier Bay, Alaska and incorporation into a tidal circulation model. Estuar Coast Shelf Sci 82:95-107

- Hill DF, Bruhis N, Calos SE, Arendt A, Beamer J (2015) Spatial and temporal variability of freshwater discharge into the Gulf of Alaska. J Geophys Res Oceans 120:634-646

$>$ Hood E, Scott D (2008) Riverine organic matter and nutrients in southeast Alaska affected by glacial coverage. Nat Geosci 1:583-587

> Hop H, Pearson T, Hegseth EN, Kovacs KM and others (2002) The marine ecosystem of Kongsfjorden, Svalbard. Polar Res 21:167-208

Ikeda T, Motoda S (1978) Estimated zooplankton production and their ammonia excretion in the Kuroshio and adjacent seas. Fish Bull 76:357-367

IPCC (2014) Climate Change 2014: Synthesis report. Contribution of Working Groups I, II and III to the Fifth Assessment Report of the Intergovernmental Panel on Climate Change. IPCC, Geneva 
Jacob T, Wahr J, Pfeffer WT, Swenson S (2012) Recent contributions of glaciers and ice caps to sea level rise. Nature 482:514-518

Juul-Pedersen $\mathrm{T}$, Arendt KE, Mortensen J, Blicher ME, Sogaard DH, Rysgaard S (2015) Seasonal and interannual phytoplankton production in a sub-Arctic tidewater outlet glacier fjord, SW Greenland. Mar Ecol Prog Ser 524:27-38

Kissling ML, Reid M, Lukacs PM, Gende SM, Lewis SB (2007) Understanding abundance patterns of a declining seabird: implications for monitoring. Ecol Appl 17: 2164-2174

Kuletz KJ, Stephensen SW, Irons DB, Labunski EA, Brenneman KM (2003) Changes in distribution and abundance of Kittlitz's murrelet Brachyramphus brevirostris relative to glacial recession in Prince William Sound, Alaska. Mar Ornithol 31:133-140

> Larsen CF, Burgess E, Arendt AA, O'Neel S, Johnson AJ, Lienholz C (2015) Surface melt dominates Alaska glacier mass balance. Geophys Res Lett 42:5902-5908

Lindquist K, Engle K, Stahlke D, Price E (2004) Global topography and bathymetry grid improves research efforts. Eos Trans AGU 85:186

> Lydersen C, Assmy P, Falk-Petersen S, Kohler J and others (2014) The importance of tidewater glaciers for marine mammals and seabirds in Svalbard, Norway. J Mar Syst 129:452-471

> Mehlum F, Gabrielsen GW (1993) The diet of high-arctic seabirds in coastal and ice-covered, pelagic areas near Svalbard archipelago. Polar Res 12:1-20

> Motyka RJ, Hunter L, Echelmeyer KA, Connor C (2003) Submarine melting at the terminus of a temperate tidewater glacier, LeConte glacier, Alaska, USA Ann Glaciol 36: 57-65

Mueter FJ, Broms C, Drinkwater KF, Friedland KD and others (2009) Ecosystem responses to recent oceanographic variability in high-latitude Northern Hemisphere ecosystems. Prog Oceanogr 81:93-110

Neal EG, Hood E, Smikrud K (2010) Contribution of glacier runoff to freshwater discharge into the Gulf of Alaska. Geophys Res Lett 37:L06404

> Nielsen JK, Hooge PN, Taggart SJ, Seitz AC (2014) Characterizing Pacific halibut movement and habitat in a Marine Protected Area using net squared displacement analysis methods. Mar Ecol Prog Ser 517:229-250

O'Neel S, Hood E, Bidlack AL, Fleming SW and others (2015) Icefield-to-ocean linkages across the northern Pacific coastal temperate rainforest ecosystem. Bioscience 65:499-512

Palma S, Silva N (2004) Distribution of siphonophores, chaetognaths, euphausiids and oceanographic conditions in the fjords and channels of southern Chile. DeepSea Res II 51:513-535

> Piatt JF, Harding AMA, Shultz M, Speckman SG, van Pelt TI, Drew GS, Kettle AB (2007) Seabirds as indicators of marine food supplies: Cairns revisited. Mar Ecol Prog Ser 352:221-234

Piatt JF, Arimitsu ML, Drew GS, Madison EN, Bodkin JL, Romano MD (2011) Status and trend of the Kittlitz's murrelet in Glacier Bay, Alaska. Mar Ornithol 75:65-75

> Pichevin LE, Ganeshram RS, Geibert W, Thunell R, Hinton R (2014) Silica burial enhanced by iron limitation in oceanic upwelling margins. Nat Geosci 7:541-546

Pinheiro JC, Bates DM (2000) Mixed-effects models in S and S-Plus. Springer Verlag, New York, NY

> Piwosz K, Walkusz W, Hapter R, Wieczorek P, Hop H, Wiktor
J (2009) Comparison of productivity and phytoplankton in a warm (Kongsfjorden) and a cold (Hornsund) Spitsbergen fjord in mid-summer 2002. Polar Biol 32:549-559

Post A, O'Neel S, Motyka RJ, Streveler G (2011) A Complex Relationship Between Calving Glaciers and Climate. Eos Trans AGU 92:305-307

> Purcell JE (2005) Climate effects on formation of jellyfish and ctenophore blooms: a review. J Mar Biol Assoc UK 85:461-476

R Development Core Team (2014) R: a language and environment for statistical computing. R Foundation for Statistical Computing, Vienna

Radic V, Bliss A, Beedlow AC, Hock R, Miles E, Cogley JG (2014) Regional and global projections of twenty-first century glacier mass changes in response to climate scenarios from global climate models. Clim Dyn 42:37-58

Redfield AC (1958) The biological control of chemical factors in the environment. Am Sci 46:205-221

> Renner M, Arimitsu ML, Piatt JF (2012) Structure of marine predator and prey communities along environmental gradients in a glaciated fjord. Can J Fish Aquat Sci 69: 2029-2045

Ridgeway G (2013) Generalized boosted regression models. R package version 2.2.1. http://cran.r-project.org/package= gbm

Robards MD, Piatt JF, Kettle AB, Abookire AA (1999) Temporal and geographic variation in fish communities of lower Cook Inlet, Alaska. Fish Bull 97:962-977

Robards MD, Drew GS, Piatt JF, Anson JM and others (2003) Ecology of selected marine communities in Glacier Bay: zooplankton, forage fish, seabirds and marine mammals. USGS Final Report, Anchorage, AK

$>$ Rose GA (2005) Capelin (Mallotus villosus) distribution and climate: a sea 'canary' for marine ecosystem change. ICES J Mar Sci 62:1524-1530

> Royer TC, Grosch CE, Mysak LA (2001) Interdecadal variability of Northeast Pacific coastal freshwater and its implications on biological productivity. Prog Oceanogr 49:95-111

> Silva N, Vargas CA, Prego R (2011) Land-ocean distribution of allochthonous organic matter in surface sediments of the Chiloé and Aysén interior seas (Chilean Northern Patagonia). Cont Shelf Res 31:330-339

Smith KL, Robison BH, Helly JJ, Kaufmann RS and others (2007) Free-drifting icebergs: hot spots of chemical and biological enrichment in the Weddell Sea. Science 317:478-482

> Speckman SG, Piatt JF, Mintevera C, Parrish J (2005) Parallel structure among environmental gradients and three trophic levels in a subarctic estuary. Prog Oceanogr 66: $25-65$

Stigebrandt A (1981) A mechanism governing the estuarine circulation in deep, strongly stratified fjords. Estuar Coast Shelf Sci 13:197-211

Straneo F, Curry RG, Sutherland DA, Hamilton GS, Cenedese C, Våge K, Stearns LA (2011) Impact of fjord dynamics and glacial runoff on the circulation near Helheim Glacier. Nat Geosci 4:322-327

Strom SL, Olson MB, Macri EL, Mordy CW (2006) Crossshelf gradients in phytoplankton community structure, nutrient utilization, and growth rate in the coastal Gulf of Alaska. Mar Ecol Prog Ser 328:75-92

Svendson H (1986) Mixing and exchange processes in estuaries, fjords and shelf waters. In: Skreslet S (ed) The role of freshwater outflow in coastal marine ecosystems. 
NATO ASI Series Vol. 7, Berlin, p 13-45

Syvitski JPM (1989) On the deposition of sediment within glacier-influenced fjords: oceanographic controls. Mar Geol 85:301-329

Syvitski JPM, Burrell DC, Skei JM (1987) Fjord processes and products. Springer-Verlag, New York, NY

Tréguer P, Nelson DM, Van Bennekom AJ, Demaster DJ, Leynaert A, Quéguiner B (1995) The silica balance in the world ocean: a reestimate. Science 268:375-379

UNESCO (1994) Protocols for the Joint Global Ocean Flux Study (JGOFS) Core Measurements. In: Knap A, Michaels A, Close A, Ducklow H, Dickson A (eds) IOC Manuals and Guides No. 29

van Etten J (2015) gdistance: distances and Routes on Geographic Grids. R package version 1.1-6. http:/CRAN.Rproject.org/package=gdistance.

Vargas CA, Martinez RA, González HE, Silva N (2008) Contrasting trophic interactions of microbial and copepod communities in a fjord ecosystem, Chilean Patagonia. Aquat Microb Ecol 53:227-242

Editorial responsibility: Just Cebrian, Dauphin Island, Alabama, USA
Waite JN, Mueter FJ (2013) Spatial and temporal variability of chlorophyll-a concentrations in the coastal Gulf of Alaska, 1998-2011, using cloud-free reconstructions of SeaWiFS and MODIS-Aqua data. Prog Oceanogr 116: 179-192

Weingartner TJ, Danielson SL, Royer TC (2005) Freshwater variability and predictability in the Alaska Coastal Current. Deep-Sea Res II 52:169-191

Williams K, Horne JK, Punt AE (2015) Examining influences of environmental, trawl gear, and fish population factors on midwater trawl performance using acoustic methods. Fish Res 164:94-101

Womble JN, Pendleton GW, Mathews EA, Blundell G, Bool NM, Gende SM (2010) Harbor seal (Phoca vitulina richardii) decline continues in the rapidly changing landscape of Glacier Bay National Park, Alaska 1992-2008. Mar Mamm Sci 26:686-697

Zajaczkowski M, Legeżyńska J (2001) Estimation of zooplankton mortality caused by an Arctic glacier outflow. Oceanologia 43:341-351

Submitted: July 10, 2015; Accepted: September 1, 2016 Proofs received from author(s): November 5, 2016 